\title{
P2X7 on mast cells participates in peripheral pain and serves as a potential target for salicylic acid and aspirin analgesia
}

\section{Yucui Jiang}

Nanjing University of Chinese Medicine

Fan Ye

Nanjing University of Chinese Medicine

Ying Du

Nanjing University of Chinese Medicine

Zongxiang Tang ( $\nabla$ njucm_m_t@njucm.edu.cn )

Nanjing University of Chinese Medicine

Research article

Keywords: ATP, mast cell, P2X7, salicylic acid and aspirin, analgesia

Posted Date: March 19th, 2021

DOI: https://doi.org/10.21203/rs.3.rs-28934/v2

License: (a) (i) This work is licensed under a Creative Commons Attribution 4.0 International License.

Read Full License 


\section{Abstract}

Background Extracellular ATP signaling through excitatory and calcium-permeable P2X receptor channels is considered as a critical player in pain generation and maintenance. P2X7 has attracted much attention over the past decade because of its prominent role in driving inflammatory processes. The role of P2X7 in mast cells in peripheral pain remains unclear.

Methods P2X expression in mouse peritoneal mast cells was detected by RT-PCR. The subtypes of P2X receptors in mouse peritoneal mast cells were determined with a series of blockers by using calcium imaging and electrophysiology. The regulation of inflammatory factors mediated by different P2X subtypes were detected by ELISA and real-time PCR. The role of mast cells and P2X7 receptor in peripheral pain was explored by behavioral assays, pathological analysis and real-time PCR. Several antiinflammatory small molecules were screened based on P2X7 in mast cells by using calcium imaging, electrophysiology and molecular docking.

Results We found that ATP was significantly increased in inflammatory pain. Mouse peritoneal mast cells expressed P2X1, P2X3, P2X4 and P2X7 and could be activated by different concentrations of extracellular ATP, which could be blocked by specific ion channel antagonists. In particularly, high concentration of ATP could induce mast cells to release inflammatory mediators such as histamine, IL-1 $\beta$ and CCL3 through P2X7 receptor. Furthermore, peripheral pain induced by high concentration of ATP could be alleviated by P2X7 blockers or mast cell defects. Interestingly, salicylic acid and aspirin could attenuate the inward current, the release of inflammatory factors and peripheral pain induced by ATP with high concentration. Furthermore, salicylic acid and aspirin also inhibited the inward current evoked by P2X7 agonist BZATP. Molecular docking results showed that salicylic acid and aspirin had affinity to the cytoplasmic GDP-binding region of P2X7.

Conclusions We concluded that P2X7 on mast cells involved in peripheral pain. Salicylic acid and aspirin could inhibit the activity of P2X7 via interacting with the GDP binding region. P2X7 receptor was a potential target for salicylic acid and aspirin analgesia.

\section{Background}

Extracellular ATP is a "signal of danger" mediated by $\mathrm{P} 2$ purinergic receptors. P2 receptors have two types, P2X (P2X1-7) and P2Y receptors [1]. P2X receptors carry out many important functions in the central and peripheral nervous system [2]. Compelling evidences have shown that P2X3, P2X4 and P2X7 receptors are involved in the pathogenesis of chronic pain [3]. P2X7 exists in neurons and glial cells of nervous, but is mainly expressed in cells of immune origin [4]. The absence of P2X7 receptor can completely eliminate the inflammatory and neuropathic hypersensitivity to both mechanical and temperature stimulation $[5,6]$. P2X7 receptor of microglia also plays an important role in chronic neuropathy and inflammatory pain by releasing IL-1 $\beta$ [7]. Besides IL-1 $\beta$, cytokines such as IL-6, CCL2, 
TNFa and CCL3 are also mediated by P2X7 receptor in neutrophil and monocyte [8-12]. Hence, P2X7 receptor represents a promising target for pain intervention.

Mast cells are in close proximity to afferents and establishing dynamic interactions with pain-activating nociceptors [13]. Performed and newly synthesized mediators released from mast cells could contribute to pain via the nervous system or other immune cells [14]. Therefore, mast cells play important roles in the pathological process of pain [15]. The classic pathway of mast cell activation is mediated by IgE receptor (FcERI). Mast cells are also activated by a wide variety of triggers, such as substance $P$, lipid mediators and interleukins [16]. Extracellular ATP also can stimulate mast cells and induce different inward currents through $\mathrm{P} 2 \mathrm{X}$ receptors [17]. Although activation of P2X4 can augment the degranulation mediated by the FcERI in mouse bone marrow-derived mast cells, only P2X7 contributes to degranulation in human mast cell line LAD2 $[18,19]$. As yet, the relationship between P2X7 receptor on mast cell and pain remains unclear.

Chronic pain is a global problem affecting more than two-thirds of the population. Extensive research has been conducted to find appropriate methods of relieving pain and improving the quality of life. Salicylic acid, an extract of willow bark, has been used for pain management as early as 4,000 years ago. Aspirin, derived from salicylic acid, is a common peripheral analgesic drug via inhibiting cyclooxygenase-1 (COX1). The analgesic effect of salicylates is apparently, however, the targets are still not entirely clear. Previous literatures indicate that salicylates are associated with mast cells. Salicylic acid can significantly inhibit histamine release from rat peritoneal mast cells activated by compound $48 / 80$ or anti-DNP IgE [20]. The relationship between aspirin and mast cells remains controversial. There are some evidences show that the anaphylaxis triggered by aspirin is due to eosinophils and mast cells [21]. High concentrations of aspirin such as $10 \mathrm{mM}$ can activate mast cells directly [22], but the effect of normal concentrations of aspirin on mast cells remains unclear.

In this study, we evaluated the roles of several P2X receptor subtypes on mast cells, especially the P2X7 receptor. In addition, we also explored the relationship between salicylates and P2X7 channel.

\section{Materials And Methods}

\section{Ethics statement}

All procedures were performed under protocols approved by the Animal Care and Use Committee of Nanjing University of Chinese Medicine.

This article does not contain any studies with human participants performed by any of the authors.

\section{Animals}

Adult male mice used were 22-28 g males in a C57BL/6 background (Qinglongshan, China). Animals were housed at constant humidity $(40-60 \%)$ and temperature $\left(22 \pm 2^{\circ} \mathrm{C}\right)$ on a $12 \mathrm{~h}$ light/dark cycle and allowed free access to food and water. C-kit mutant genetically mast cell-deficient Kit (W-sh) "sash" mice and MrgprB2Cre ${ }^{\text {Td/tomato }}$ mice were donated by Johns Hopkins. 


\section{Chemicals}

ATP (Sigma-Aldrich, St. Louis, MO, United States), PPADS (20 $\mu \mathrm{M}$, Abcam, USA, a non-selective P2 purinergic receptor antagonist), NF449 $(1 \mu \mathrm{M}$, Cayman, USA, P2X1 receptor antagonist), AF-353 (0.1 $\mu \mathrm{M}$, donated by China Pharmaceutical University, P2X3 receptor antagonist), 5-BDBD (1 $\mathrm{M}$, Sigma-Aldrich, United States, P2X4 receptor antagonist), AZ10606120 (1 $\mu \mathrm{M}$, Tocris Bioscience, USA, P2X7 receptor antagonist), BzATP (30 $\mu \mathrm{M}$, Alomone Labs, Israel, P2X7 receptor agonist), recombinant mouse SCF protein (10 ng/mL, R\&D Systems, USA), penicillin and streptomycin (100 $\mathrm{g} / \mathrm{mL}$; Gibco, USA), fibronectin (30 $\mathrm{gg} / \mathrm{mL}$; Sigma-Aldrich, United States), Fluo 4-AM (Solarbio, China, calcium indicator), Histamine ELISA Kit (Yifeixue, China), Trizol (Vazyme Biotech, China), HiScript II Q RT SuperMix for qPCR (Vazyme Biotech, China), Taq MasterMix (Vazyme Biotech, China), AceQ qPCR SYBR Green Master Mix (Vazyme Biotech, China), ATP Content Assay Kit (Yifeixue, China), salicylic acid (Yuanye Biotech, China), aspirin (Yuanye Biotech, China).

\section{ATP measurement}

ATP was measured through an ATP Content Assay Kit (Yifeixue, China) following manufacturer's instructions. The paw tissue (about $10 \mathrm{mg}$ ) homogenate was centrifuged at $8000 \mathrm{~g}$ for $10 \mathrm{~min}$ at $4^{\circ} \mathrm{C}$, and the supernatant was collected. Then treated with chloroform, and the supernatant was collected for ATP content detection.

\section{P815 cell culture and mouse peritoneal mast cell purification}

Mouse Mastocytoma Cells (P815) was cultured in 1640 complete medium ( $90 \% 1640$ medium, 10\% fetal bovine serum, $100 \mu \mathrm{g} / \mathrm{ml}$ penicillin and $100 \mu \mathrm{g} / \mathrm{ml}$ streptomycin). Cells were maintained at $37^{\circ} \mathrm{C}$ in a humidified atmosphere of $5 \% \mathrm{CO} 2$ incubator.

Mouse peritoneal mast cells were established from C57BL/6 mice as Dong's Lab described [23]. Briefly, the mouse peritoneal cells were collected with mast cell dissociation media MCDM (HBSS with $10 \mathrm{mM}$ HEPES and 3\% fetal bovine serum, $\mathrm{pH} 7.2$ ), and then centrifuged at $200 \mathrm{~g}$ for $5 \mathrm{~min}$. The pellet was resuspended and layered over $70 \%$ percoll suspension, and then centrifuged at $500 \mathrm{~g}$ for $20 \mathrm{~min}$. Pipetted off supernatant carefully and the mast cells were washed with fresh MCDM. Mast cells were resuspended in DMEM containing $10 \%$ fetal bovine serum and $10 \mathrm{ng} / \mathrm{mL}$ recombinant mouse stem cell factor. As supplementary Fig.S1 shown, the extracted mouse peritoneal mast cell was identified by toluidine blue staining, and the purity was about $90 \%$.

\section{P2X purinoceptors RT-PCR screen}

Trizol method was used to isolate total RNA from mouse peritoneal mast cells or the mouse mastocytoma cells. 10-500 ng RNA was used for reverse transcription reaction by using HiScript II Q RT SuperMix for qPCR Kit according to the manufacturer's instructions. Polymerase chain reaction conditions were as follows: $95^{\circ} \mathrm{C}$ for $5 \mathrm{~min}, 40$ cycles of $15 \mathrm{~s}$ at $95^{\circ} \mathrm{C}, 30 \mathrm{~s}$ at $60^{\circ} \mathrm{C}$, and $1 \mathrm{~min}$ at $72^{\circ} \mathrm{C}$, and $10 \mathrm{~min}$ at $72^{\circ} \mathrm{C} .10 \mu \mathrm{L}$ of the PCR reaction product was used for agarose gel electrophoresis and stained with Gold View and then observed by ChemiDoc MP (Bio-rad, California, USA). All of the PCR primers were 
synthesized by Genescipt Biotechnology (Nanjing, China). The primer sequence and product size are shown in Table 1.

Table 1

The sequence of primers

\begin{tabular}{|c|c|c|}
\hline Gene & Primer sequence (5'-3') & Product size \\
\hline \multirow[t]{2}{*}{$\mathrm{P} 2 \mathrm{X} 1$} & Forward: GCCCAAGGTATTCGCACAGG & \multirow[t]{2}{*}{$496 \mathrm{bp}$} \\
\hline & Reverse: GACGACGGTTTGTCCCATTCT & \\
\hline \multirow[t]{2}{*}{$\mathrm{P} 2 \mathrm{X} 2$} & Forward: ACCTGCCATTTAGATGACGACTG & \multirow[t]{2}{*}{$241 \mathrm{bp}$} \\
\hline & Reverse: TGTTGCCCTTGGAGAACTTGA & \\
\hline \multirow[t]{2}{*}{ P2X3 } & Forward: GCTTCGGACGCTATGCCAACA & \multirow[t]{2}{*}{$490 \mathrm{bp}$} \\
\hline & Reverse: AAATCCTGCCCAGCAAACTTAA & \\
\hline \multirow[t]{2}{*}{$\mathrm{P} 2 \mathrm{X} 4$} & Forward: GTGCTCGGGTCCTTCCTGTTC & \multirow[t]{2}{*}{$154 \mathrm{bp}$} \\
\hline & Reverse: CCGTTTCCTGGTAGCCCTTTT & \\
\hline \multirow[t]{2}{*}{ P2X5 } & Forward: TGTAGCGGGACACGGACTGA & \multirow[t]{2}{*}{$209 \mathrm{bp}$} \\
\hline & Reverse: TTTCTAGCACATTGGCTTTGGA & \\
\hline \multirow[t]{2}{*}{ P2X6 } & Forward: GGTACAACTTCAGGACAGCCAATC & \multirow[t]{2}{*}{$207 \mathrm{bp}$} \\
\hline & Reverse: CATACAGTAGCAGCAGGTCACAGAG & \\
\hline \multirow[t]{2}{*}{ P2X7 } & Forward: AACATCTTGCCAACTATGAACGG & \multirow[t]{2}{*}{$132 \mathrm{bp}$} \\
\hline & Reverse: ТССТСССТGAАСТGССАССТ & \\
\hline
\end{tabular}

\section{Intracellular calcium measurement}

The mouse peritoneal mast cells were isolated and plated on the glass cover slips, which coated by 30 $\mu \mathrm{g} / \mathrm{mL}$ fibronectin. After two hours of incubation, mast cells were incubated by $1 \mu \mathrm{L} / \mathrm{mL}$ Fluo- 4 calcium ion indicator along with $0.02 \%$ Pluronic F-127 for 30 minutes at room temperature. Then cells immediately washed for 3 times by calcium imaging buffer $(125 \mathrm{mM} \mathrm{NaCl}, 3 \mathrm{mM} \mathrm{KCl}, 2.5 \mathrm{mM} \mathrm{CaCl}, 0.6$ $\mathrm{mM} \mathrm{MgCl}_{2}, 20 \mathrm{mM}$ glucose, $10 \mathrm{mM} \mathrm{HEPES}, 20 \mathrm{mM}$ sucrose, $1.2 \mathrm{mM} \mathrm{NaHCO}_{3}, \mathrm{pH}$ 7.4). Finally, cells were imaged at 488-nm excitation to detect intracellular free calcium within two hours. Each experiment was done at least three times, and at least 200 cells were analyzed each time.

\section{Wholecell current-clamp recordings of mouse peritoneal mast cells}

The patch pipettes typically had a resistance of 4-6 M $\Omega$, and the osmolality was adjusted to $300-310$ mOsM (adjusted by sucrose as necessary). The standard pipette solution contained $135 \mathrm{mM} \mathrm{CsCl,} 8 \mathrm{mM}$ 
$\mathrm{NaCl}, 10 \mathrm{mM}$ EGTA, $3.6 \mathrm{mM} \mathrm{CaCl}$, $10 \mathrm{mM}$ HEPES, $2 \mathrm{mM}$ Mg-ATP (added when detecting P2X7 channel), $\mathrm{PH} 7.3$ (adjusted by $\mathrm{CsOH}$ ). The standard external solution contained $147 \mathrm{mM} \mathrm{NaCl}, 2 \mathrm{mM} \mathrm{KCl}, 2 \mathrm{mM}$ $\mathrm{CaCl}_{2}, 1 \mathrm{mM} \mathrm{MgCl}_{2} \cdot 6 \mathrm{H}_{2} \mathrm{O}, 10 \mathrm{mM}$ HEPES, $16 \mathrm{mM}$ glucose, $\mathrm{pH} 7.3$ (adjusted by $\mathrm{NaOH}$ ). Low divalent external solution contained $147 \mathrm{mM} \mathrm{NaCl}, 10 \mathrm{mM}$ HEPES, $13 \mathrm{mM}$ glucose, $0.2 \mathrm{mM} \mathrm{CaCl}, 2 \mathrm{mM} \mathrm{KCl}, \mathrm{pH}$ 7.3 (adjusted by $\mathrm{NaOH}$ ).

All the experiments were performed at room temperature. Whole-cell currents were record by using Multiclamp 700 B and Digidata 1440 A (Molecular Devices, Inc., San Jose, USA), capacitance transients and series resistance were minimized by using the capacitance neutralization circuits on the amplifier. Experiments were performed with a perfusion system, and drugs were directly added to the recording chamber with a pipette. The cells were usually evoked by holding the membrane potential, and applied voltage commands to a range of potentials with $10 \mathrm{mV}$ steps from $-130 \mathrm{mV}$ to $+130 \mathrm{mV}$ in $100 \mathrm{~ms}$. In addition, currents were evoked by ramping the membrane potential from $-90 \mathrm{mV}$ to $+100 \mathrm{mV}$ in $300 \mathrm{~ms}$. The currents were digitized (sampled at a frequency of $10 \mathrm{kHz}$ and filtered at $0.1 \mathrm{kHz}$ for analysis), stored and subsequently analyzed by using Clampex 10.3 (Molecular Devices, Inc., San Jose, USA).

\section{Quantitative Real-time PCR}

Total RNA from Mouse Mastocytoma Cells (about $10^{5}-10^{6}$ cells) stimulated by different concentration of ATP for 4 or 0.5 hours ( $5 \mathrm{mM}$ ATP), tissues $(10-50 \mathrm{mg}$ ) isolated from paw treated with $100 \mathrm{mM}$ ATP or saline were prepared by using Trizol reagent. cDNA was generated by HiScript II Q RT SuperMix for qPCR Kit according to the manufacturer's instructions. Real-time qPCR was performed using AceQ qPCR SYBR Green Master Mix and GAPDH were used as internal controls. The primer sequences are shown in Table 2 . 
Table 2

The sequence of primers

\begin{tabular}{|c|c|}
\hline Gene & Primer sequence (5'-3') \\
\hline \multirow[t]{2}{*}{ IL-6 } & Forward: GTTGCCTTCTTGGGACTGAT \\
\hline & Reverse: CTGGCTTTGTCTTTCTTGTTAT \\
\hline \multirow[t]{2}{*}{ IL-1 $\beta$} & Forward: AAATCTCGCAGCAGCACATC \\
\hline & Reverse: AGCAGGTTATCATCATCATCCC \\
\hline \multirow[t]{2}{*}{ CCL2 } & Forward: GGCCTGCTGTTCACAGTTGC \\
\hline & Reverse: CAGAAGTGCTTGAGGTGGTTG \\
\hline \multirow[t]{2}{*}{ CCL3 } & Forward: GCTCCCAGCCAGGTGTCATT \\
\hline & Reverse: CAGGCATTCAGTTCCAGGTCAG \\
\hline \multirow[t]{2}{*}{ GAPDH } & Forward: GCACAGTCAAGGCCGAGAAT \\
\hline & Reverse: GCCTTCTCCATGGTGGTGAA \\
\hline
\end{tabular}

\section{Histamine ELISA}

Histamine ELISA prepared according to the manufacturer's protocol. Briefly, mouse peritoneal mast cells were stimulated with different concentration of ATP $(1 \mu \mathrm{M}, 100 \mu \mathrm{M}, 1 \mathrm{mM}$ and $5 \mathrm{mM})$, and the supernatants were harvested at time point of $0.5 \mathrm{~h}$ and stored at $80^{\circ} \mathrm{C}$ until used for ELISA.

\section{Behavioral assays}

The Von Frey behavioral assays were performed in a blinded manner. In briefly, different groups of mice were put in a transparent plastic box, which was placed on a metal mesh for about $30 \mathrm{~min}$. Then the value of threshold was measured with a time interval of $1 \mathrm{~h}, 3 \mathrm{~h}, 5 \mathrm{~h}$ after $100 \mathrm{mM}$ ATP treatment. Each mouse was tested by at least 10 times at a specific force $(0.16 \mathrm{~g})$ manually.

\section{Histological}

The paw skin was isolated and washed, and then fixed with $4 \%$ paraformaldehyde for $24 \mathrm{~h}$, and then treated with $30 \%$ sucrose for $48 \mathrm{~h}$. The tissue was embedded in OCT and sliced to a thickness of 10 microns, followed by hematoxylin-eosin (HE) staining and toluidine blue staining. Images of each section were obtained by using the Nikon ECLIPSE 80i microscope (Nikon, Tokyo, Japan) with a magnification of 200.

\section{Molecular docking}

The discovery Studio 20164.0 software was used to verify the molecular docking. We downloaded the three-dimensional structure of salicylic acid (PubChem CID: 338) and aspirin (PubChem CID: 2244) from 
the NCBI PubChem Compound database (http://www.ncbi.nlm.nih.gov/pccompound) and the monomeric crystal structure of P2X7 (PDB ID: 6U9V) from the Research Collaboratory for Structure Bioinformatics (RCSB) Protein Data Bank (http://www.rcsb.org/pdb).

\section{Quantification and statistical analysis}

The data were analyzed by GraphPad 6.0 and presented as mean \pm SEM, ${ }^{*} p<0.05,{ }^{* *} p<0.01,{ }^{* * *} p<0.001$, ${ }^{\#} p<0.05,{ }^{\# \#} p<0.01,{ }^{\# \#} p<0.001$ was considered statistically significant. Statistical analysis of the results was performed by two-tailed, unpaired or paired Student's T-test or ANOVA analysis.

\section{Results}

\section{$\mathrm{P} 2 \mathrm{X}$ receptors expression and ATP-induced calcium response in mouse peritoneal mast cells}

Upon for instance tissue stress, hypoxia or inflammation, ATP is released from cells into the extracellular environment leading to the increase in extracellular ATP. Our results also showed that ATP was significantly increased in inflammatory pain such as CFA $(0.4913 \pm 0.04 \mu \mathrm{mol} / \mathrm{g}$ vs $1.116 \pm 0.09 \mu \mathrm{mol} / \mathrm{g}$, ${ }^{\star \star *} p<0.001$, Supplementary Fig. S2). Because mast cells play important roles in the pathological process of pain, we speculate that $\mathrm{P} 2 \mathrm{X}$ receptors on mast cells involved in this function.

First, to identify P2X receptors on mast cell, we explored the P2X expression in mouse peritoneal mast cells by RT-PCR screen. As shown in Fig. $1 \mathrm{~A}$, we found that mouse peritoneal mast cells expressed several different ionotropic $\mathrm{P} 2 \mathrm{X}$ receptors including $\mathrm{P} 2 \mathrm{X} 1, \mathrm{P} 2 \mathrm{X} 3, \mathrm{P} 2 \mathrm{X} 4$ and $\mathrm{P} 2 \mathrm{X} 7 . \mathrm{P} 2 \mathrm{X}$ receptor is a non-selective cation channel, the most obvious permeability to $\mathrm{Ca}^{2+}$. Hence, we examined the calcium influx in mouse peritoneal mast cells induced by ATP. The results showed that there were transient increases of intracellular calcium in mast cells treated by different concentrations of ATP (Fig. 1B, C). The ratios of fluorescence intensity were varied with different ATP concentrations, and EC50 was about $6.5 \mu \mathrm{M}$ (Fig. 1C). In addition to fluorescence intensity, the reaction durations also existed differences (Fig. 1B), which indicated that different concentrations of ATP could activate mast cells through different P2X ionotropic receptors.

To confirm that, we used special P2X channel antagonists. As shown in Fig. 1D-H, the calcium influx caused by different concentrations of ATP could be partially blocked by a non-selective P2 purinergic receptor antagonist PPADS ( $20 \mu \mathrm{M}$, pre-incubation for 5 minutes). In addition, calcium influx caused by 1 $\mu \mathrm{M}$ ATP was inhibited by P2X1 receptor antagonist NF449 (1 $\mu \mathrm{M}$, pre-incubation for 5 minutes) (Fig. 1D). AF-353 (P2X3 receptor antagonist, $0.1 \mu \mathrm{M}$, pre-incubation for 5 minutes) could reduce the calcium influx caused by $10 \mu \mathrm{M}$ ATP (Fig. 1E). And the transient increase of the intracellular calcium induced by $100 \mu \mathrm{M}$ ATP was blocked by 5-BDBD ( $1 \mu \mathrm{M}$, pre-incubation for 5 minutes) (Fig. 1F), which is a specific P2X4 receptor antagonist. Furthermore, the specific P2X7 receptor antagonist AZ10606120 (1 $\mu \mathrm{M}$, preincubation for 5 minutes) had the ability of reducing the calcium influx caused by high concentration ATP such as $1 \mathrm{mM}$ and $5 \mathrm{mM}$ (Fig. 1G, H). These results indicated that P2X1, P2X3, P2X4 and P2X7 might contribute to the activation of mouse peritoneal mast cells. 
Electrophysiological characteristics of mouse peritoneal mast cells induced by extracellular ATP

According to previously published literature, human mast cells are sensitive to ATP in a concentrationdependent manner [17]. Our experimental results proved that mouse peritoneal mast cells had the same characteristics. About $85 \%$ of mast cells were sensitive to $1 \mu \mathrm{M}$ ATP (Fig. $2 \mathrm{~A}, \mathrm{n}=17$ ). The inward current could also be induced by $100 \mu \mathrm{M}$ ATP (Fig. 2B, $n=21$ ). When we increased the concentration of extracellular ATP to a high level, we found that both $1 \mathrm{mM}$ and $5 \mathrm{mM}$ ATP had the ability to induce the inward currents repeatedly (Fig. 2C, $n=9$; Fig. 2D, $n=8$ ). As Fig. 2E, F shown, the current characteristics evoked by various concentrations of extracellular ATP were different from each other, including the amplitude of the inward current and the current durations. Although the current amplitude as well as the duration were different between $1 \mathrm{mM}$ ATP and $5 \mathrm{mM}$ ATP, the inward currents had some similar characteristics such as "run-up" tendency (Fig. 2G, H). The current growth rate of second ATP application had no difference as Fig. 2I shown. The current growth rate is defined as. Furthermore, the inward current evoked by $1 \mathrm{mM}$ ATP was voltage-dependent (Fig. 2J-L). The activate curves and inactivate curves induced by $5 \mathrm{mM}$ ATP were shown in Fig. 2M. According these curves, the conductance curve was calculated as shown in Fig. $2 \mathrm{~N}$, which indicated that the current induced by $5 \mathrm{mM}$ ATP had characteristics with faster activation and slower inactivation.

\section{Inward currents induced by extracellular ATP with different concentrations could be blocked by P2X1, P2X3, P2X4 and P2X7 antagonist}

Electrophysiological results showed that there were different currents corresponding to ATP with different concentrations. Therefore, we speculated that several $\mathrm{P} 2 \mathrm{X}$ receptor subtypes contributed to the activation progress. As Wareham described, P2X1,P2X4 and P2X7 receptors in LAD2 were activated by $1 \mu \mathrm{M}$ ATP, $100 \mu \mathrm{M}$ ATP and high concentrations of ATP, respectively [17]. In our study, we also found that $1 \mu \mathrm{M}$ ATP hardly induced inward current when $20 \mu \mathrm{M}$ PPADS (a non-selective P2 antagonist) (Fig. 3A, G, n = 9) or $1 \mu \mathrm{M}$ NF449 (the blocker of P2X1 receptor) (Fig. $3 A, G, n=13$ ) was applied, which indicated that P2X1 was activated by $1 \mu \mathrm{M}$ ATP. As Fig. 3B, H shown, $20 \mu \mathrm{M}$ PPADS $(n=9)$ or $0.1 \mu \mathrm{M}$ AF-353 (the blocker of P2X3 receptor, $n=10$ ) could reduce the current evoked by $10 \mu \mathrm{M}$ ATP, which indicated that P2X3 was activated by $10 \mu \mathrm{M}$ ATP. In addition, P2X4 was involved in the current induced by $100 \mu \mathrm{M}$ ATP, which was blocked by $1 \mu \mathrm{M}$ 5-BDBD (Fig. 3C, I, $\mathrm{n}=10$ ) or $20 \mu \mathrm{M}$ PPADS (Fig. 3C, I, $\mathrm{n}=13$ ). The current caused by $1 \mathrm{mM}$ ATP were inhibited by using $1 \mu \mathrm{M}$ AZ 10606120 (the blocker of P2X7 receptor) (Fig. 3D, J, $n=5$ ). The current induced by $5 \mathrm{mM}$ ATP could also be inhibited by AZ 10606120 (Fig. 3E, $K, n=6$ ). These results demonstrated that $\mathrm{P} 2 \mathrm{X} 7$ receptor was activated by high concentrations of ATP such as $1 \mathrm{mM}$ and $5 \mathrm{mM}$. Intrestingly, we found that $20 \mu \mathrm{M}$ PPADS could partially inhibit the current induced by $1 \mathrm{mM}$ ATP (Supplementary Fig. S3A, S3C), but had no effect on the current evoked by 5 mM ATP (Supplementary Fig. S3B, S3D), which indicated that PPADS might have limited inhibitory effect on P2X7. Furthermore, P2X7 receptor was sensitive to divalent cation as North described [24]. Consequently, our results illustrated that the inward current induced by $5 \mathrm{mM}$ ATP in the low divalent cation was greater than that in normal external solution (Fig. 3F, L), which confirmed that the existence of P2X7 in mouse peritoneal 
mast cells. Taken together, results confirmed that P2X1, P2X3, P2X4 and P2X7 expressed in mouse peritoneal mast cells and involved in the progress activation induced by extracellular ATP.

\section{Activation of P2X7 receptor on mouse-derived mast cell could lead to degranulation and de novo synthesis of cytokines}

Degranulation is one of important indicators of mast cell activation. Consistent with the research by Wareham et al in human mast cell line LAD2 [18], our results indicated that there is no detectable histamine release at lower concentrations of ATP such as $1 \mu \mathrm{M}$ ATP and $100 \mu \mathrm{M}$ ATP. However, histamine released from mouse peritoneal mast cells was significantly increased at higher concentrations of ATP (Fig. 4A). Besides histamine, mast cells are effective producers of inflammatory cytokines in response to various stimuli. According to previous literatures, cytokines secretion especially IL-1 $\beta$ induced by the extracellular ATP has been widely studied in different immune cells [8-12]. However, the release of cytokines from mast cells induced by extracellular ATP remains unclear. To examine the potential mediator release in mast cells, we detected a serious of mediators such as IL-6, IL-1 $\beta$, CCL2 and CCL3. Due to the mouse peritoneal mast cells are too few to detect, we turned to mouse mastocytoma cells P815, which also expressed P2X1, P2X3, P2X4 and P2X7 receptors (Supplementary Fig. S4). Data in Fig. 4B-H demonstrated that the regulation of inflammatory mediators was related to the concentration as well. There was no significant change or up-regulated slightly in the expression of cytokines when treated with low concentration of ATP (Fig. 4B-D). ATP with high concentrations could significantly upregulate the expression of a variety of inflammatory cytokines, such as IL-1 $\beta$ and CCL3 (Fig. 4E, G). In addition, we found that cytokines were regulated slightly after treatment with $5 \mathrm{mM}$ ATP for 4 hours, but IL-1 $\beta$ and CCL3 were significantly up-regulated after treatment for 0.5 hours, which might be related with the negative feedback caused by high ATP concentration (Fig. 4F, G). AZ10606120, a specific P2X7 receptor antagonist ( $5 \mu \mathrm{M}$, pre-incubation for 5 minutes), almost completely inhibited the upregulation of IL-1 $\beta$ and CCL3 induced by $1 \mathrm{mM}$ ATP (Fig. 4H). Therefore, we concluded that P2X7 receptor on mast cells could mediate mast cell degranulation and de novo synthesis of inflammatory factors such as IL-1 $\beta$ and CCL3.

\section{High concentration of ATP could induce peripheral pain in mice by activating P2X7 channel on mast cells}

Our experimental results indicated that $\mathrm{P} 2 \mathrm{X} 7$ receptor on mast cell had the function of releasing inflammatory mediators, which might contribute to pain via neuro-immune interactions. We assumed that mast cells and P2X7 receptor promoted the peripheral pain induced by high concentration of ATP. In order to prove this hypothesis, we utilized the mast cell-deficient Kit (W-sh) Sash mutant mice and P2X7 receptor antagonist. Firstly, results showed that high concentration of ATP $(100 \mathrm{mM}, 20 \mu \mathrm{L}, \mathrm{iH})$ did induce paw swelling (Fig. 5A, C), inflammatory cells infiltration (Fig. 5B), mast cells degranulation (Fig. 5D) and mechanical hyperalgesia (Fig. 5E). As our expected, mast cell-deficient mice could alleviate ATP-induced pain including paw swelling, mechanical withdrawal threshold and the infiltration of inflammatory cells (Fig. 5A-E). To further explore the mechanism, we also tested the inflammatory mediators. The RT-PCR data showed that the mRNA expression levels of IL-6, IL-1 $\beta, C C L 2$ and CCL3 were significantly 
upregulated for the C57/BL mice. However, only IL-6 and CCL3 were slightly upregulated for the Sash mice. In comparison with the C57/BL mice, the degree of upregulation of IL-1 3, CCL2 and CCL3 for the Sash mice was reduced (Fig. 5F). At the same time, we also studied the function of P2X7 receptor in high concentration of ATP-induced peripheral pain. Our experimental results showed that AZ10606120 (specific P2X7 receptor antagonist, $2 \mathrm{mg} / \mathrm{kg}$, ip, pre-administration $1 \mathrm{~h}$ ) could significantly reduce the pain behavior and paw thickness at 4 h after ATP treatment (Fig. 5G, H).

\section{$\mathrm{P} 2 \mathrm{X7}$ on mast cells is a potential target for salicylic acid and aspirin analgesia}

P2X7 is an appealing target for anti-inflammatory therapy, so we used P2X7 as an analgesic target to screen several anti-inflammatory substances monomers. We found that Matrine, Higenamine, Dictamnine, Prim-O-glucosylcimifugin, Liquiritin, Menthol, Ferulic Acid, 3-Hydroxy-4-methoxycinnamic acid, Isoginkgetin, Vanillic acid, Luteolin, Isoliquiritigenin or Aloeemodin had no inhibitory effect on the current evoked by high concentration of ATP (Supplementary Table 1). Interestingly, salicylic acid and aspirin could inhibit the inward current generated by high concentration of ATP as Fig. 6A shown.

Compared with the current amplitude induced by first ATP application, $300 \mu \mathrm{M}, 500 \mu \mathrm{M}$ or $1 \mathrm{mM}$ salicylic acid could slightly inhibit the current amplitude induced by second ATP application (Fig. 6B-D, n=21, $\mathrm{n}=$ 14 and $n=16$ respectively). It is worth noting that the current induced by $5 \mathrm{mM}$ ATP had a "run-up" tendency, which indicated that the current growth rate should be studied. Data showed that the current growth rate of second ATP application was significantly inhibited by salicylic acid as Fig. 6E shown. 500 $\mu \mathrm{M}$ or $1 \mathrm{mM}$ aspirin could also inhibit the current amplitude induced by $5 \mathrm{mM}$ ATP (Fig. $6 \mathrm{G}-\mathrm{H}, \mathrm{n}=6, \mathrm{n}=8$ and $n=20$ respectively). The current growth rate was significantly inhibited by $500 \mu \mathrm{M}$ or $1 \mathrm{mM}$ aspirin

(Fig. 6l). The intercellular $\mathrm{Ca}^{2+}$ concentration assay results also showed that $300 \mu \mathrm{M}$ salicylic acid or 1 $\mathrm{mM}$ aspirin could also inhibit 5mM ATP-induced calcium influx (Supplementary Fig. S5). At the same time, we also explored the effects of drugs on inflammatory mediators. As our expected, $300 \mu \mathrm{M}$ salicylic acid or $1 \mathrm{mM}$ aspirin could attenuate the up-regulation of IL-1 $\beta$ and CCL3 mediated by high concentration of ATP, especially IL-1 $\beta$ (Fig. $6 \mathrm{~J}$ ). Results from behavioral test indicated that salicylic acid $(50 \mathrm{mg} / \mathrm{kg}$, ig) or aspirin $(50 \mathrm{mg} / \mathrm{kg}$, ig) could also alleviate the peripheral pain induced by high concentration of ATP (Fig. 6K). To further clarify the relationship between salicylates and P2X7 receptor, we used the P2X7 receptor agonist BzATP. Results showed that $300 \mu \mathrm{M}$ salicylic acid $(n=18)$ or $300 \mu \mathrm{M}$ aspirin $(n=7)$ significantly inhibited the current growth rate (Fig. 6L) and the calcium influx (Supplementary Fig. S6) evoked by BzATP. These experimental results suggested that P2X7 on mast cells might be a potential target for salicylic acid and aspirin analgesia.

\section{GDP binding region is the critical for the combination of salicylic acid and aspirin with P2X7}

Our experimental results have shown that the analgesic effect of salicylic acid and aspirin may be achieved by inhibiting P2X7 channel. Next, we want to know how salicylic acid and aspirin work in combination with P2X7. To uncover this mystery, molecular docking was used to analyze the interaction between salicylic acid or aspirin and P2X7 by Discovery Studio software. As shown in Fig. 7, salicylic acid (Fig. 7G-L) and its derivative aspirin (Fig. 7A-F) had affinity to the GDP-binding region of P2X7, including A: GDP 703, B: GDP703 and C: GDP704 ligands. Among these, aspirin has the highest affinity with A: GDP 
703 ligand as Fig. 7A, B shown. The - $\mathrm{COOH}$ of aspirin formed two Electrostatic-bonds with Arg546 (R546) and Arg578 (R578) of A: GDP 703 ligand, and van der Waals-bonds with Ser589 (S589). Consistent with the electrophysiological and the intercellular $\mathrm{Ca}^{2+}$ concentration assay results, we considered that salicylic acid and aspirin could inhibit P2X7 activation by directly binding the receptor.

\section{Discussion}

It is well-known that P2X3 and P2X4 in the nervous system were involved in the pathogenesis of neuropathic pain [25]. A more recent player in chronic pain is the P2X7 receptor in immune cells. The high threshold activation gives P2X7 a role in damage-sensing, only triggering downstream effects when ATP concentration is pathologically elevated [26]. In neuroinflammatory and neurodegenerative diseases, P2X7 upregulation and function appears to contribute to disease progression [26]. P2X7 receptor mediates NLRP3 inflammasome activation, cytokine and chemokine release, T lymphocyte survival and differentiation, transcription factor activation, and cell death [27]. P2X7 promotes release of proinflammatory factors, such as IL-1 $\beta$, IL-6, CCL2, TNFa and CCL3 [8-12]. Hence, P2X7 is an appealing target for anti-inflammatory therapy. However, the relationship between P2X7 on mast cells and the pathogenesis of pain is still not illustrated. Our study aimed to explore the roles of P2X receptor subtypes on mast cells in inflammatory pain, especially the P2X7 receptor. At the same time, we also used P2X7 as an analgesic target to screen several anti-inflammatory small molecule compounds.

Firstly, we found that several functional P2X receptors including ionotropic P2X1, P2X3, P2X4 and P2X7 existed in mouse peritoneal mast cells. The expression profile was similar to that previously observed in mouse bone marrow mast cells, LAD2 and human lung mast cells which express P2X1, P2X4 and P2X7. Furthermore, calcium image results demonstrated that ATP could also activate mouse peritoneal mast cells in a concentration-dependent manner. The blocker results indicated that P2X1, P2X3, P2X4 and P2X7 were involved in the calcium influx caused by $1 \mu \mathrm{M}$ ATP, $10 \mu \mathrm{M}$ ATP, $100 \mu \mathrm{M}$ ATP and high concentration ATP ( $1 \mathrm{mM}$ and $5 \mathrm{mM}$ ) respectively. Notably, specific P2X inhibitors only partially inhibited the increase of concentration of the intracellular calcium. It indicated that the process also be associated with other receptors. For example, previous literatures have shown that besides P2X4, P2Y2 could be stimulated by ATP with a concentration of $100 \mu \mathrm{M}$ [19].

Just as other cell models, extracellular ATP provoked distinct inward currents in mouse peritoneal mast cells as well. P2X1 receptor was characterized by fast activation and desensitization [24]. Our results demonstrated the current induced by $1 \mu \mathrm{M}$ ATP was closely resemble for P2X1-like current, which could be eliminated by non-selective P2 antagonists PPADS as well as P2X1-selective antagonist NF449. PPADS or P2X3-selective antagonist AF-353 could block the inward current induced by $10 \mu \mathrm{M}$ ATP, which suggested that P2X3 participated in this activation process. In addition, the current evoked by $100 \mu \mathrm{M}$ ATP could be blocked by PPADS or 5-BDBD, indicating that P2X4 receptor was involved. Unlike LAD2 and HLMC [17], the P2X1-like and P2X4-like current in mouse peritoneal mast cells did not exhibit 'run-down' phenomenon upon repeated application. The reason for this may be due to the heterogeneous of mast cells [28]. Our results showed that both $1 \mathrm{mM}$ ATP and $5 \mathrm{mM}$ ATP could induce P2X7-like currents with 
'run-up' characteristic, which is in line with the conclusion reported by other literatures [17, 24]. Although the current evoked by $1 \mathrm{mM}$ ATP and $5 \mathrm{mM}$ ATP existed some differences, AZ10606120 could block both of them. Hence, we confirmed that P2X7 was involved in the activation caused by $1 \mathrm{mM}$ ATP and $5 \mathrm{mM}$ ATP.

Compelling of researches pointed out several substances including histamine, tryptase, cytokines and chemokines released from mast cells could contribute to pain either directly or indirectly [15]. We also explored the mediators released from mast cells induced by ATP. The data showed that ATP with high concentration could induce histamine release, which was consistent with previous report $[15,19]$. In addition to degranulation, high concentration of ATP also promoted the upregulation and secretion of inflammatory mediators. Our study showed that ATP with high concentration could significantly upregulate IL-1 $\beta$ and CCL3, which could be blocked by AZ10606120. These results indicated that P2X7 receptor was involved in mast cells degranulation and release of inflammatory mediators. Neuronimmune crosstalk plays important roles in many inflammatory diseases, we suggested P2X7 on mast cells could also induce peripheral pain indirectly as demonstrated in Fig. 8. Histamine plays a critical role in neurogenic inflammation and pain transmission via specific receptors in a bidirectional manner [15, 29]. IL-1 $\beta$ can modulate neuronal activity directly, in addition, IL-1 $\beta$ also mediate pain sensitization via IL1 receptor. Blocking spinal IL-1 signaling could alleviate neuropathic pain [30, 31]. Furthermore, the roles of inflammatory chemokines could regulate synaptic transmission, especially CCL2/CCR2 and CCL3/CCR1 signaling $[32,33]$. Consistent with the hypothesis, our results also demonstrated mast cell and $\mathrm{P} 2 \mathrm{X} 7$ participated in the peripheral pain.

Chronic pain is a serious global health issue and a huge clinical challenge without available effective treatment. The commonly used pain-relieving agents are often associated with harmful side effects such as addiction. Therefore, the discovery of novel therapeutic alternatives with superior effectiveness and minimal adverse effects would be beneficial. Hence, we screened several anti-inflammatory molecule compounds based on P2X7 receptor. Interestingly, we found that salicylic acid and aspirin could inhibit the inward current and calcium influx induced by high concentration ATP or P2X7 agonist BZATP. Salicylic acid and aspirin could also attenuate the release of inflammatory factors and peripheral pain induced by high concentration ATP. Molecular docking results showed that salicylic acid and aspirin had affinity to the cytoplasmic GDP-binding region of P2X7. Therefore, the analgesic mechanism salicylic acid and aspirin may be the inhibition of P2X7 activity by binding to GDP-binding region. needs further exploration. The binding patterns and the binding sites of salicylic acid and aspirin to the P2X7 receptor still need to be further verified.

\section{Conclusion}

In summary, we found that mouse-derived mast cells could be activated by extracellular ATP via P2X1, $\mathrm{P} 2 \mathrm{X} 3, \mathrm{P} 2 \mathrm{X} 4$ and P2X7 receptors. Mast cells and P2X7 receptor on mast cells played important roles in peripheral pain via inflammatory mediators. In addition, we also found that P2X7 receptor may be a potential target for the analgesic drugs salicylate acid and aspirin. 


\section{Abbreviations}

ATP: Adenosine-triphosphate

IL-1 $\beta$ : Interleukin-1 $\beta$

IL-6: Interleukin-6

CCL2: C-C motif chemokine 2

CCL3: C-C motif chemokine 3

BZATP: 3'-O-(4-Benzoylbenzoyl)ATP;3'-O-(4-Benzoylbenzoyl)-ATP

GDP: Guanosine diphosphate)

MrgprB2: MAS-related GPR member B2

PPADS: 4-[[4-Formyl-5-hydroxy-6-methyl-3-[(phosphonooxy)methyl]-2-pyridinyl]azo]-1,3-benzenedisulfonic acid tetrasodium salt

NF449: 4,4',4",4"'-[Carbonylbis(imino-5,1,3-benzenetriyl-bis(carbonylimino))]tetrakis-1,3-benzenedisulfonic acid

AF-353: 5-(5-iodo-2-isopropyl-4-methoxyphenoxy)pyrimidine-2,4-diamine

5-BDBD: 5-(3-Bromophenyl)-1,3-dihydro-2H-benzofuro[3,2-e]-1,4-diazepin-2-one

AZ10606120: 2-(1-adamantyl)-N-[2-[2-(2-hydroxyethylamino)ethylamino]quinolin-5-yl]acetamide

SCF: Stem cell growth factors

SA: Salcylic acid

ASA: Acetylsalicylic acid

\section{Declarations}

\section{Consent for publication}

Not applicable.

\section{Availability of data and materials}

The datasets used and/or analysed during the current study are available from the corresponding author on reasonable request. 


\section{Competing interests}

The authors declare that they have no competing interests.

\section{Funding}

The study was financially supported by National Natural Science Foundation of China (No. 31771163) and Innovative Project of postgraduate education in Jiangsu Province (No. 021093002404).

\section{Authors' contributions}

Zongxiang Tang designed and wrote the paper, Yucui Jiang, Fan Ye and Ying Du performed experiments, analyzed the data, and wrote part of the paper. All authors read and approved the final manuscript.

\section{Acknowledgments}

The authors thank Prof. Xinzhong Dong in Johns Hopkins for kindly providing the Mast cell-deficient Kit (W-sh) "Sash" mutant mice and MrgprB2Cre ${ }^{\text {Td/tomato }}$ mice. The authors thank Prof. Ye Yu in China Pharmaceutical University for kindly providing the P2X3 receptor antagonist AF-353.

\section{References}

1. Jacobson KA, Muller CE (2016) Medicinal chemistry of adenosine, P2Y and P2X receptors. Neuropharmacology 104:31-49

2. Franceschini A, Adinolfi E (2014) P2X receptors: New players in cancer pain. World J Biol Chem 5(4):429-436

3. Kuan YH, Shyu BC (2016) Nociceptive transmission and modulation via P2X receptors in central pain syndrome. Mol Brain 9(1):58

4. Tewari M, Seth $P$ (2015) Emerging role of $P 2 X 7$ receptors in CNS health and disease. Ageing Res Rev 24(Pt B):328-342

5. Broom DC, Matson DJ, Bradshaw E, Buck ME, Meade R, Coombs S, Matchett M, Ford KK, Yu W, Yuan J, Sun SH, Ochoa R, Krause JE, Wustrow DJ, Cortright DN (2008) Characterization of N-(adamantan1-ylmethyl)-5-[(3R-amino-pyrrolidin-1-yl)methyl]-2-chloro-benzamide, a P2X7 antagonist in animal models of pain and inflammation. J Pharmacol Exp Ther 327(3):620-633

6. McGaraughty S, Chu KL, Namovic MT, Donnelly-Roberts DL, Harris RR, Zhang XF, Shieh CC, Wismer CT, Zhu CZ, Gauvin DM, Fabiyi AC, Honore P, Gregg RJ, Kort ME, Nelson DW, Carroll WA, Marsh K, Faltynek CR, Jarvis MF (2007) P2X7-related modulation of pathological nociception in rats. Neuroscience 146(4):1817-1828

7. Chessell IP, Hatcher JP, Bountra C, Michel AD, Hughes JP, Green P, Egerton J, Murfin M, Richardson J, Peck WL, Grahames CBA, Casula MA, Yiangou Y, Birch R, Anand P, Buell GN (2005) Disruption of the P2X7 purinoceptor gene abolishes chronic inflammatory and neuropathic pain. Pain 114(3):386-396 
8. Ferrari D, Pizzirani C, Adinolfi E, Lemoli RM, Curti A, Idzko M, Panther E, Di Virgilio F (2006) The P2X7 receptor: a key player in IL-1 processing and release. J Immunol 176(7):3877-3883

9. Karmakar M, Katsnelson MA, Dubyak GR, Pearlman E (2016) Neutrophil P2X7 receptors mediate NLRP3 inflammasome-dependent IL-1 beta secretion in response to ATP. Nat Commun 7:10555

10. Kataoka A, Tozaki-Saitoh H, Koga Y, Tsuda M, Inoue K (2009) Activation of P2X7 receptors induces CCL3 production in microglial cells through transcription factor NFAT. J Neurochem 108(1):115-125

11. Parzych K, Zetterqvist AV, Wright WR, Kirkby NS, Mitchell JA, Paul-Clark MJ (2017) Differential role of pannexin-1/ATP/P2X7 axis in IL-1beta release by human monocytes. FASEB J 31(6):2439-2445

12. Shieh CH, Heinrich A, Serchov T, van Calker D, Biber K (2014) P2X7-dependent, but differentially regulated release of IL-6, CCL2, and TNF-alpha in cultured mouse microglia. Glia 62(4):592-607

13. Luo J, Feng J, Liu S, Walters ET, Hu H (2015) Molecular and cellular mechanisms that initiate pain and itch. Cell Mol Life Sci 72(17):3201-3223

14. Xu H, Bin NR, Sugita S (2018) Diverse exocytic pathways for mast cell mediators. Biochem Soc Trans 46(2):235-247

15. Gupta K, Harvima IT (2018) Mast cell-neural interactions contribute to pain and itch. Immunol Rev 282(1):168-187

16. Yu Y, Blokhuis BR, Garssen J, Redegeld FA (2016) Non-IgE mediated mast cell activation. Eur J Pharmacol 778:33-43

17. Wareham K, Vial C, Wykes RC, Bradding P, Seward EP (2009) Functional evidence for the expression of P2X1, P2X4 and P2X7 receptors in human lung mast cells. Br J Pharmacol 157(7):1215-1224

18. Wareham KJ, Seward EP (2016) P2X7 receptors induce degranulation in human mast cells. Purinergic Signal 12(2):235-246

19. Yoshida K, Ito M, Matsuoka I (2017) Divergent regulatory roles of extracellular ATP in the degranulation response of mouse bone marrow-derived mast cells. Int Immunopharmacol 43:99107

20. Kim HM, Shin HY, Choo YK, Park JK (1999) Inhibition of mast cell-dependent anaphylaxis by sodium salicylate. Immunology 96(4):551-556

21. Steinke JW, Payne SC, Borish L (2016) Eosinophils and Mast Cells in Aspirin-Exacerbated Respiratory Disease. Immunol Allergy Clin North Am 36(4):719-734

22. Steinke JW, Negri J, Liu L, Payne SC, Borish L (2014) Aspirin activation of eosinophils and mast cells: implications in the pathogenesis of aspirin-exacerbated respiratory disease. J Immunol 193(1):4147

23. McNeil BD, Pundir P, Meeker S, Han L, Undem BJ, Kulka M, Dong X (2015) Identification of a mastcell-specific receptor crucial for pseudo-allergic drug reactions. Nature 519(7542):237-241

24. North RA (2002) Molecular physiology of P2X receptors. Physiol Rev 82(4):1013-1067

25. Burnstock G (2016) Purinergic Mechanisms and Pain. Adv Pharmacol 75:91-137 
26. Savio LEB, de Andrade Mello P, da Silva CG, Coutinho-Silva R (2018) The P2X7 Receptor in Inflammatory Diseases: Angel or Demon? Front Pharmacol 9:52

27. Di Virgilio F, Dal Ben D, Sarti AC, Giuliani AL, Falzoni S (2017) The P2X7 Receptor in Infection and Inflammation. Immunity 47(1):15-31

28. Ennion SJ, Evans RJ (2001) Agonist-stimulated internalisation of the ligand-gated ion channel P2X(1) in rat vas deferens. FEBS Lett 489(2-3):154-158

29. Rosa AC, Fantozzi R (2013) The role of histamine in neurogenic inflammation. Br J Pharmacol 170(1):38-45

30. Gao YJ, Ji RR (2010) Targeting astrocyte signaling for chronic pain. Neurotherapeutics 7(4):482-493

31. Zhang RX, Li A, Liu B, Wang L, Ren K, Zhang H, Berman BM, Lao L (2008) IL-1ra alleviates inflammatory hyperalgesia through preventing phosphorylation of NMDA receptor NR-1 subunit in rats. Pain 135(3):232-239

32. Liou JT, Lee CM, Day YJ (2013) The immune aspect in neuropathic pain: role of chemokines. Acta Anaesthesiol Taiwan 51(3):127-132

33. Zhang ZJ, Jiang BC, Gao YJ (2017) Chemokines in neuron-glial cell interaction and pathogenesis of neuropathic pain. Cell Mol Life Sci 74(18):3275-3291

\section{Table S1}


Table S1

The effects of anti-inflammatory drugs on the current growth rate evoked by $5 \mathrm{mM}$ ATP.

\begin{tabular}{|lllll|}
\hline Drug Names & Drug concentrations & P value & N & Inhibitory \\
\hline Matrine & $100 \mu \mathrm{mol} / \mathrm{L}$ & 0.188 & 3 & No \\
\hline Higenamine & $50 \mu \mathrm{mol} / \mathrm{L}$ & 0.3584 & 4 & No \\
\hline Dictamnine & $10 \mu \mathrm{mol} / \mathrm{L}$ & 0.7841 & 3 & No \\
\hline Prim-O-glucosylcimifugin & $10 \mu \mathrm{mol} / \mathrm{L}$ & 0.9592 & 3 & No \\
\hline Liquiritin & $60 \mu \mathrm{mol} / \mathrm{L}$ & 0.3069 & 3 & No \\
\hline Menthol & $500 \mu \mathrm{mol} / \mathrm{L}$ & 0.5496 & 3 & No \\
\hline Ferulic Acid & $100 \mu \mathrm{mol} / \mathrm{L}$ & 0.8702 & 3 & No \\
\hline 3-Hydroxy-4-methoxycinnamic acid & $100 \mu \mathrm{mol} / \mathrm{L}$ & 0.6239 & 3 & No \\
\hline Isoginkgetin & $20 \mu \mathrm{mol} / \mathrm{L}$ & 0.101 & 4 & No \\
\hline Vanillic acid & $2 \mu \mathrm{mol} / \mathrm{L}$ & 0.1504 & 5 & No \\
\hline Luteolin & $3 \mu \mathrm{mol} / \mathrm{L}$ & 0.155 & 4 & No \\
\hline Isoliquiritigenin & $30 \mu \mathrm{mol} / \mathrm{L}$ & 0.6593 & 4 & No \\
\hline Aloeemodin & $6 \mu \mathrm{mol} / \mathrm{L}$ & 0.1903 & 6 & No \\
\hline
\end{tabular}

\section{Figures}




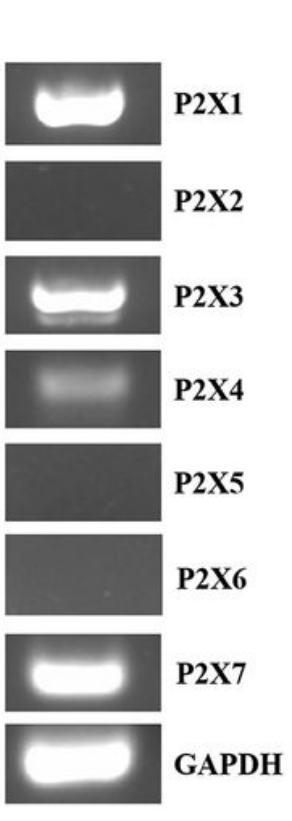

E

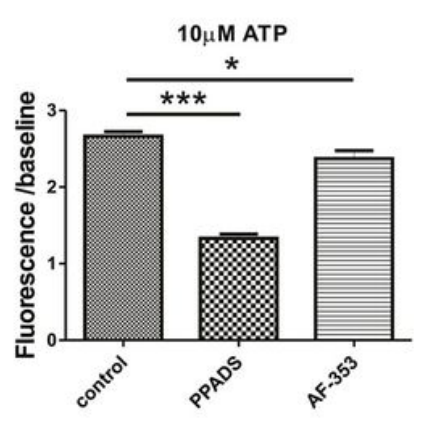

control
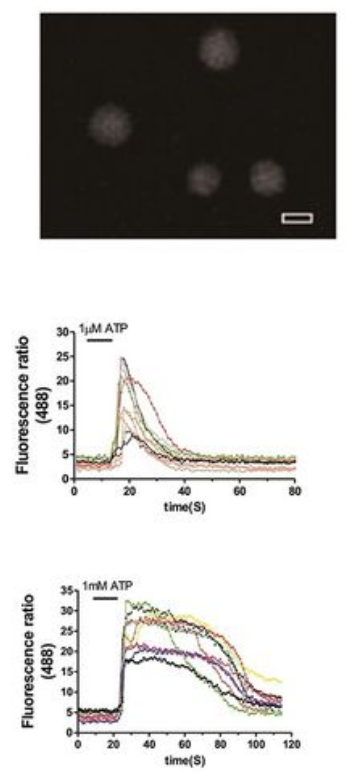

ATP
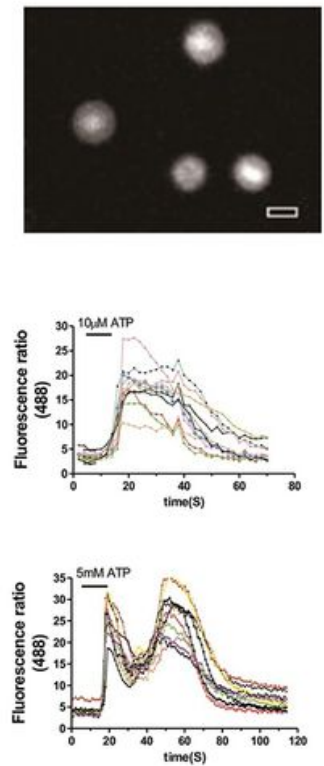

wash
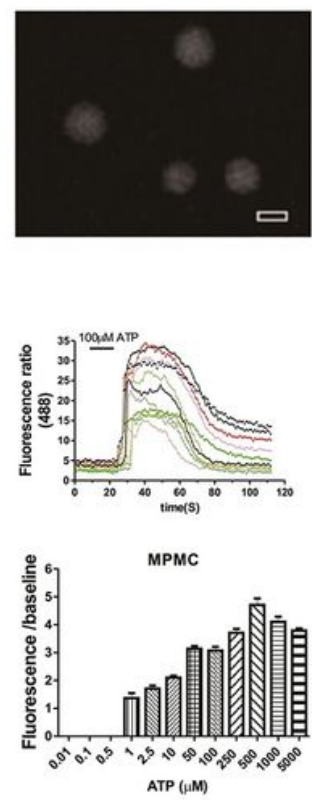

G

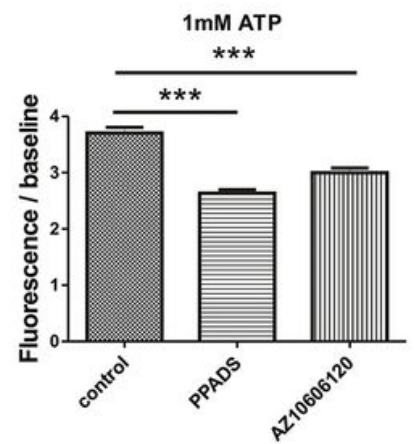

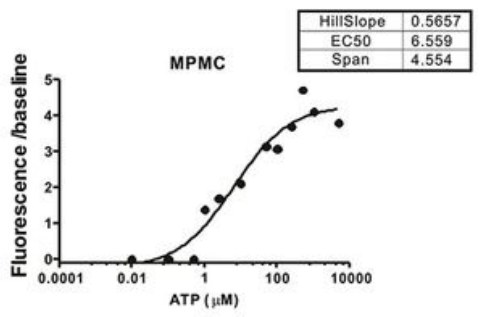

D

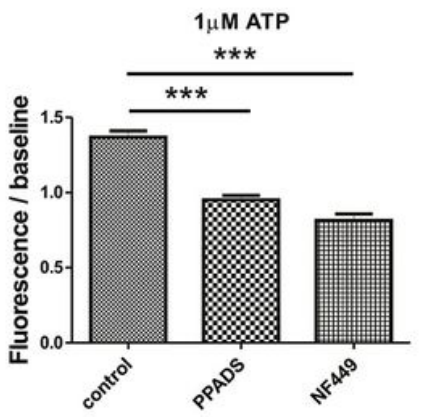

$\mathrm{H}$

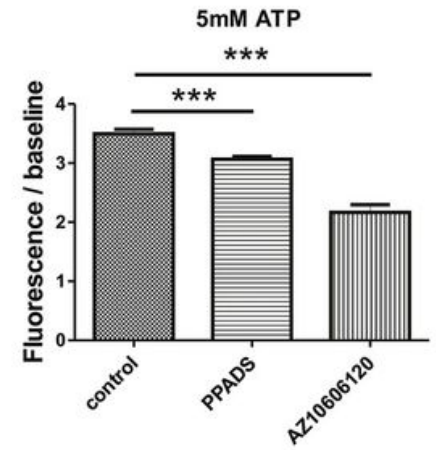

Figure 1

P2X receptors expression and ATP-induced calcium response in mouse peritoneal mast cells. (A) P2X1, P2X3, P2X4 and P2X7 expressed in mouse peritoneal mast cells. (B) Calcium influx mediated by different concentrations of extracellular ATP. (C) Fluorescence intensity induced by different concentrations of ATP from 0.01 to $5000 \mu \mathrm{M}$ is different, and the EC50 was about $6.5 \mu \mathrm{M}$. (D) The calcium influx induced by 1 $\mu \mathrm{M}$ ATP was inhibited by PPADS or NF449 (*** $p<0.001$, control vs PPADS or NF449). (E) The calcium influx induced by $10 \mu \mathrm{M}$ ATP was blocked by PPADS or AF-353 (*** $p<0.001$, control vs PPADS or AF353). (F) The calcium influx induced by $100 \mu \mathrm{M}$ ATP was blocked by PPADS or 5-BDBD ( ${ }^{\star \star \star} \mathrm{p}<0.001$, control vs PPADS or 5-BDBD). (G) The calcium influx induced by $1 \mathrm{mM}$ ATP was blocked by PPADS or AZ10606120 ( $* \star \star ~ p<0.001$, control vs PPADS or AZ10606120). (H) The calcium influx induced by $5 \mathrm{mM}$ ATP was blocked by PPADS or AZ10606120 ( $\star \star \star ~ p<0.001$, control vs PPADS or AZ10606120). 
A

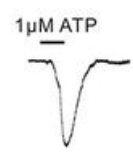

$\underbrace{100 \mathrm{pA}}_{1 \mathrm{~S}}$

E

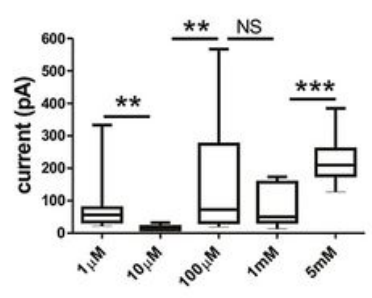

I

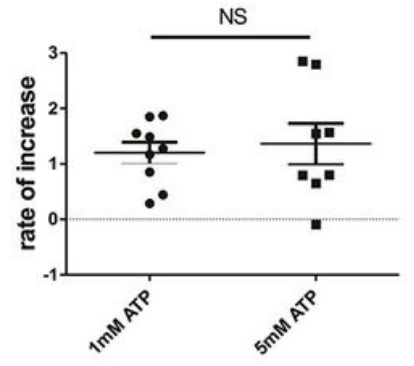

L

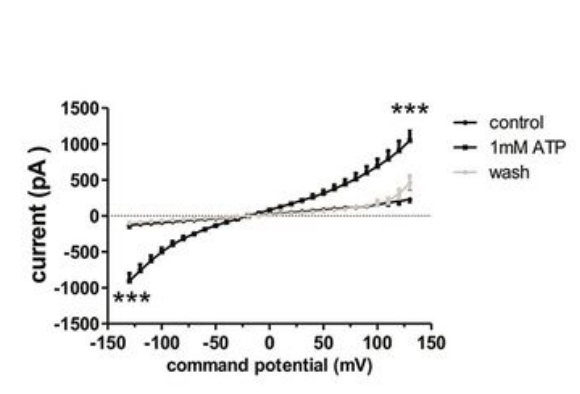

C

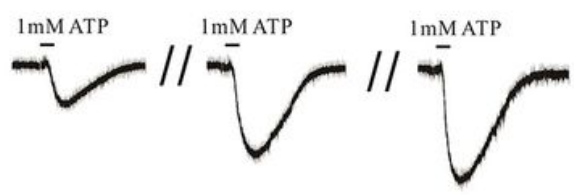

$\prod_{20 \mathrm{~S}} 100 \mathrm{pA}$
D

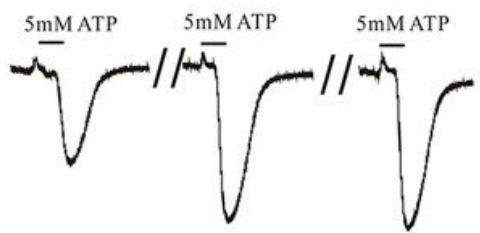

$\prod_{20 \mathrm{~S}} 100 \mathrm{pA}$

\section{F}

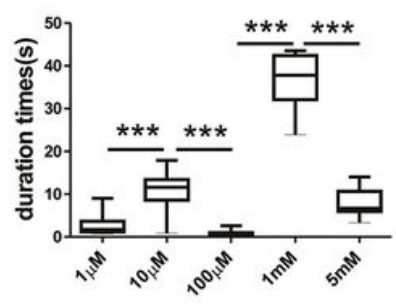

J

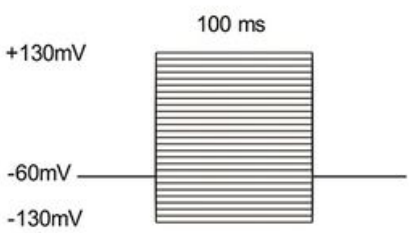

M

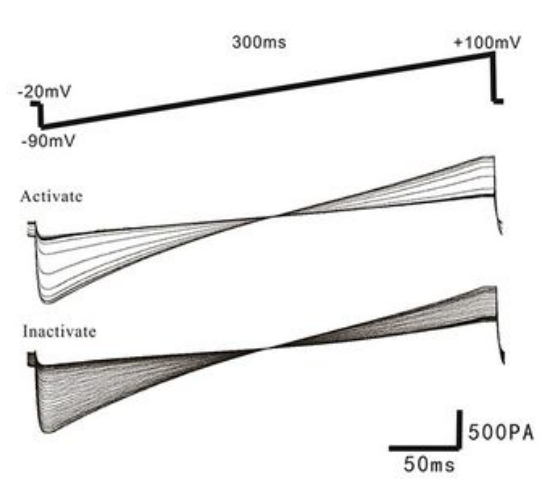

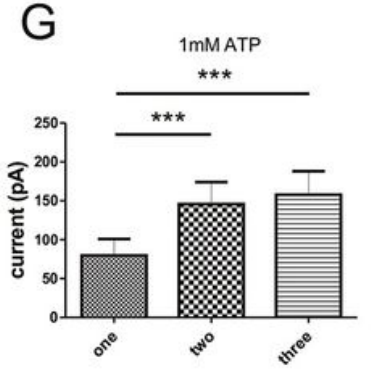

$\mathrm{H}$

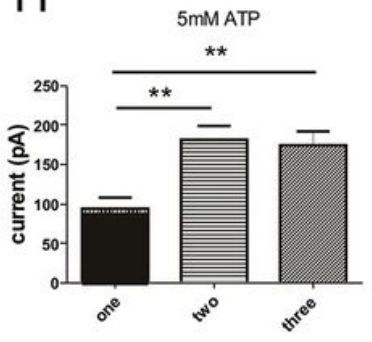

K

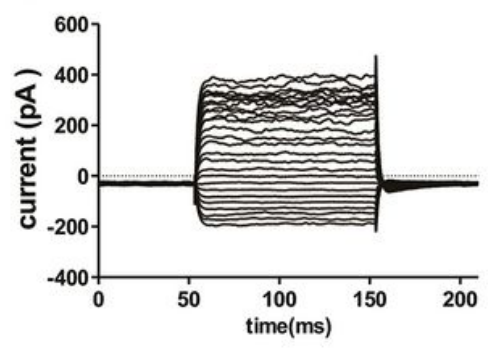

$\mathrm{N}$

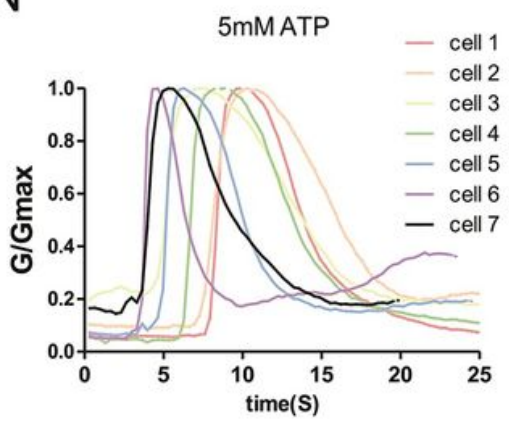

Figure 2

The inward currents evoked by ATP in mouse peritoneal mast cells. (A-D) Different types of currents induced by different concentrations of ATP $(1 \mu \mathrm{M}, 10 \mu \mathrm{M}, 100 \mu \mathrm{M}, 1 \mathrm{mM}$ and $5 \mathrm{mM}$ ATP respectively). (E) The amplitude of inward currents evoked by various concentrations of extracellular ATP were different from each other $(\star \star p<0.01, \star \star \star p<0.001)$. (F) The time durations of inward currents evoked by various concentrations of extracellular ATP were different from each other ( $\star \star \star ~ p<0.001)$. $(G, H)$ The "run-up" tendency for $1 \mathrm{mM}$ and $5 \mathrm{mM}$ ATP induced. (I) There was no significant difference in the current growth 
rate between $1 \mathrm{mM}$ ATP with $5 \mathrm{mM}$ ATP induced. (J-L) The relationship between the voltage and the current induced by $1 \mathrm{mM}$ ATP. (M) The activate curves and inactivate curves induced by $5 \mathrm{mM}$ ATP. (N) The conductance curve of 5 mM ATP induced. ${ }^{*} p<0.05, * * p<0.01, * * * p<0.001$.
A
B
C

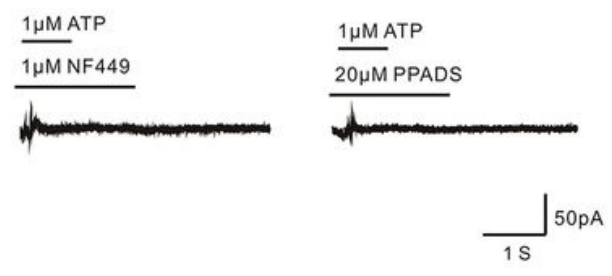

D

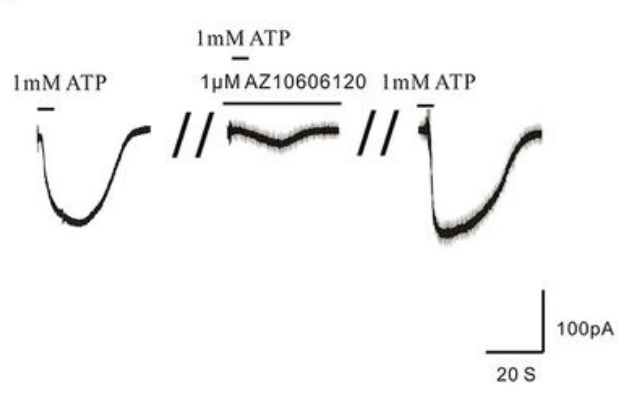

E
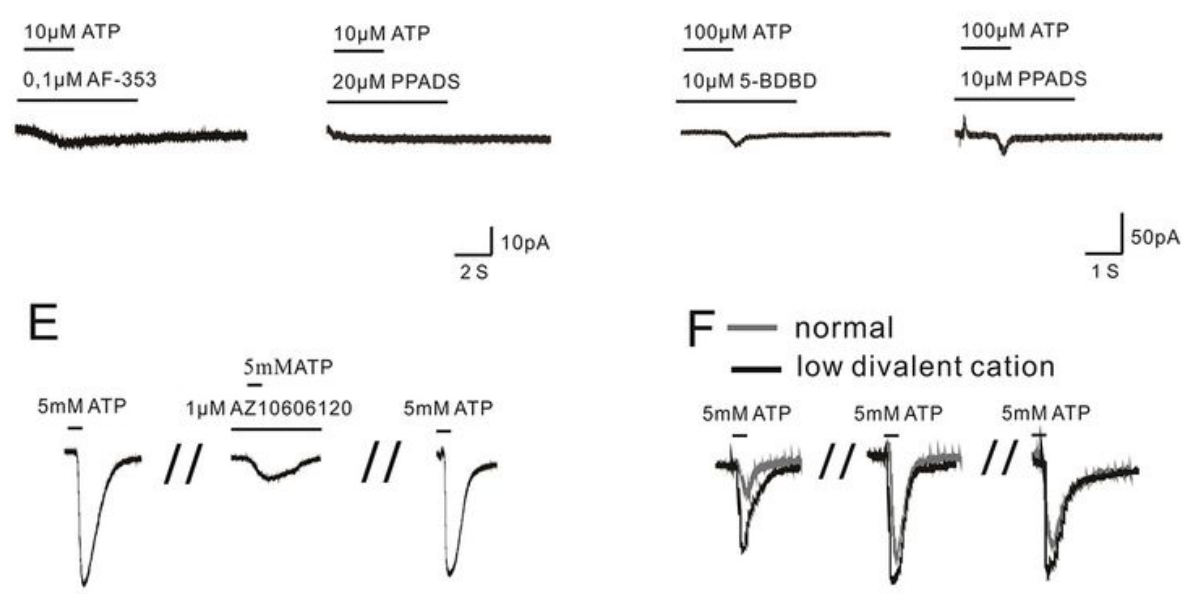

G

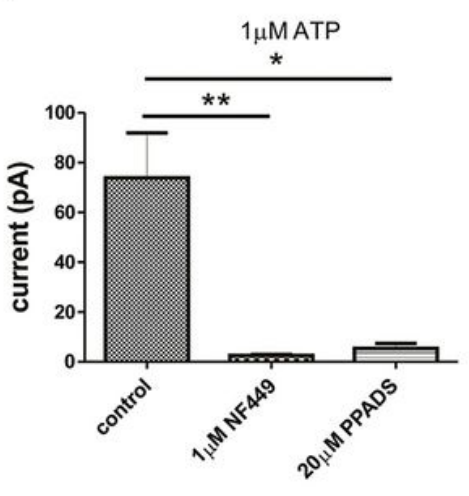

$\mathrm{H}$

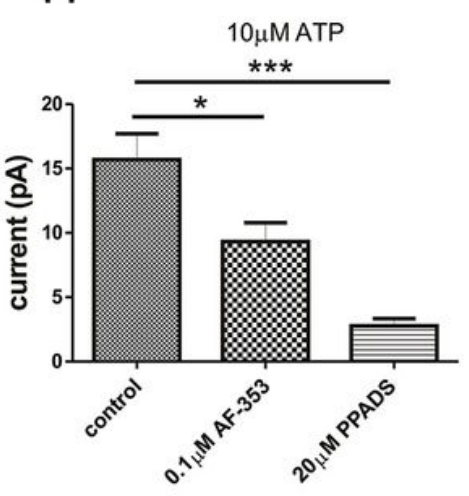

$\mathrm{F}$ - normal

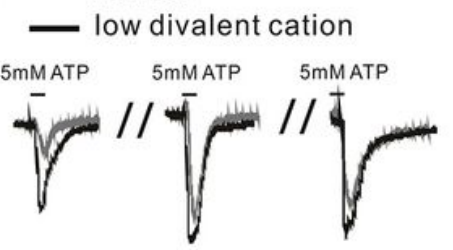

$\prod_{10 \mathrm{~S}} 100 \mathrm{pA}$
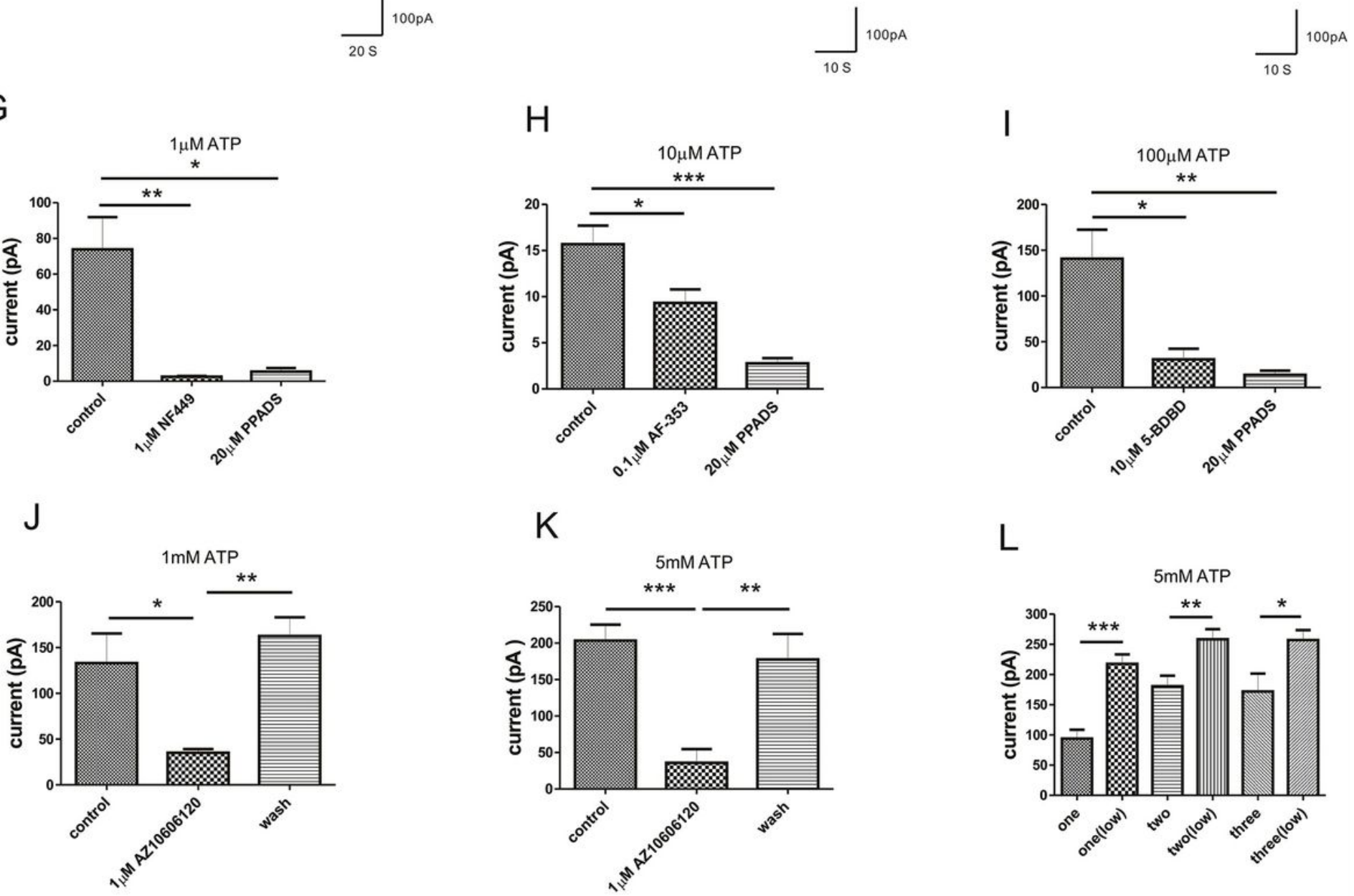

$\mathrm{L}$

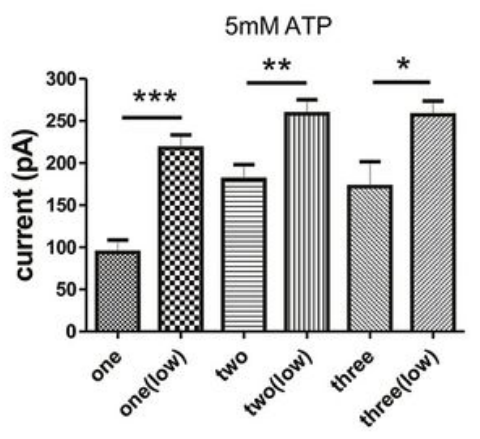

Figure 3

The effects of specific blockers on the currents activated by extracellular ATP. (A) Cell with $20 \mu M$ PPADS or $1 \mu \mathrm{M}$ NF449 hardly evoke current by $1 \mu \mathrm{M}$ ATP treatment. (B) Current evoked by $10 \mu \mathrm{M}$ ATP could be blocked by $20 \mu \mathrm{M}$ PPADS or $0.1 \mu \mathrm{M}$ AF-353. (C) The current induced by $100 \mu \mathrm{M}$ ATP could be blocked by 
$20 \mu \mathrm{M}$ PPADS or $1 \mu \mathrm{M}$ 5-BDBD. (D) The current induced by $1 \mathrm{mM}$ ATP could be blocked by $1 \mu \mathrm{M}$ AZ10606120. (E) $1 \mu \mathrm{M}$ AZ10606120 could inhibit the current evoked by $5 \mathrm{mM}$ ATP. (F) 5mM ATP could evoke greater inward current in the low divalent cation external solution. (G) The current amplitude induced by $1 \mu \mathrm{M}$ ATP could be inhibited by PPADS or NF449 ( ${ }^{*} p<0.05$, control vs $20 \mu \mathrm{M}$ PPADS, $n=9$, ** $p<0.01$, control vs $1 \mu \mathrm{M}$ NF449, $n=13)$. (H) The current amplitude evoked by $10 \mu \mathrm{M}$ ATP was blocked by PPADS or AF-353 (*** $p<0.001$, control vs $20 \mu \mathrm{M}$ PPADS, $n=9$, * $p<0.05$, control vs $0.1 \mu \mathrm{M}$ AF-353, $\mathrm{n}=10$ ). (I) PPADS or 5-BDBD could inhibit the current amplitude evoked by $100 \mu \mathrm{M}$ ATP ( $* \star p<0.01$, control vs $20 \mu$ M PPADS, $n=13$, *** $p<0.001$, control vs $1 \mu M$ 5-BDBD, $n=10)$. (J) The current amplitude evoked by $1 \mathrm{mM}$ ATP was blocked by AZ10606120 ( $\mathrm{p}<0.05$, control vs $1 \mu \mathrm{M}$ AZ10606120, $n=5$ ). (K) The current amplitude evoked by 5mM ATP could also be blocked by AZ10606120 (*** $p<0.001$, control vs 1 $\mu \mathrm{M}$ AZ10606120, n=6). (L) The current amplitude induced by 5mM ATP in the low divalent cation external solution $(n=8)$ was greater than that in the normal external solution $(n=13)$. 
A
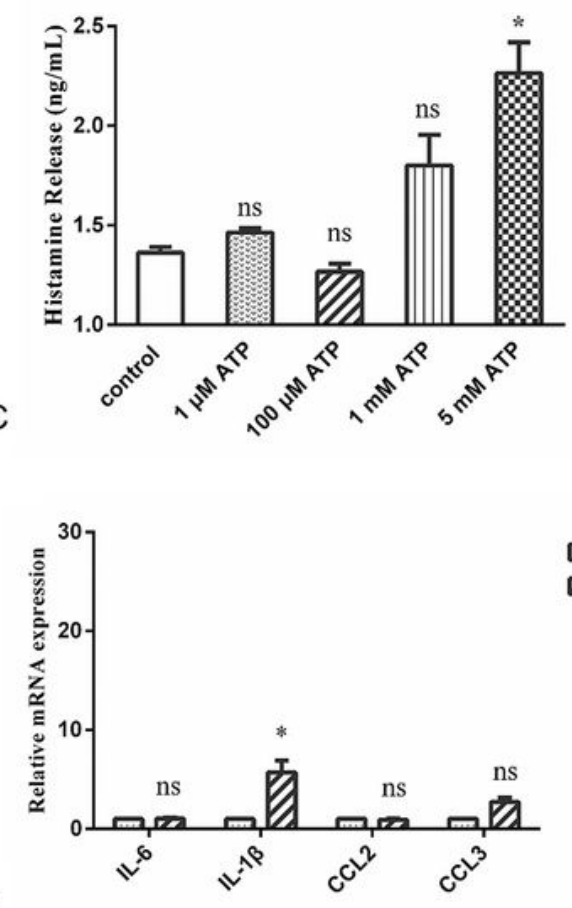

E

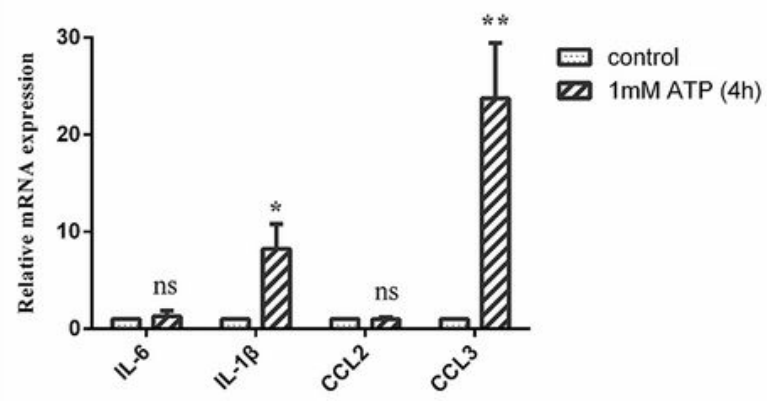

G

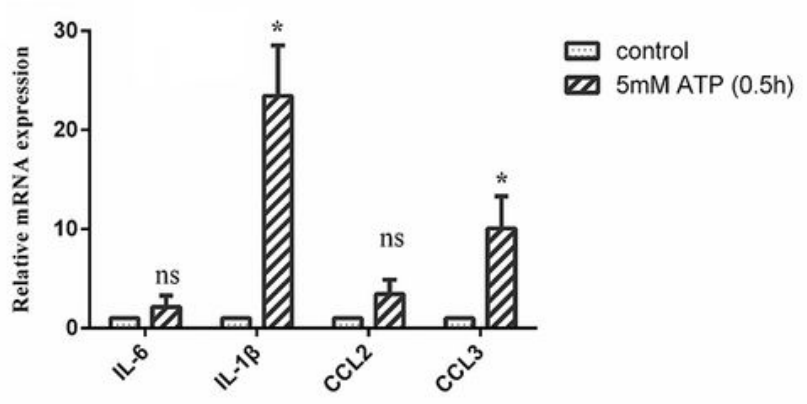

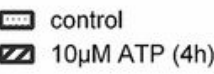

B
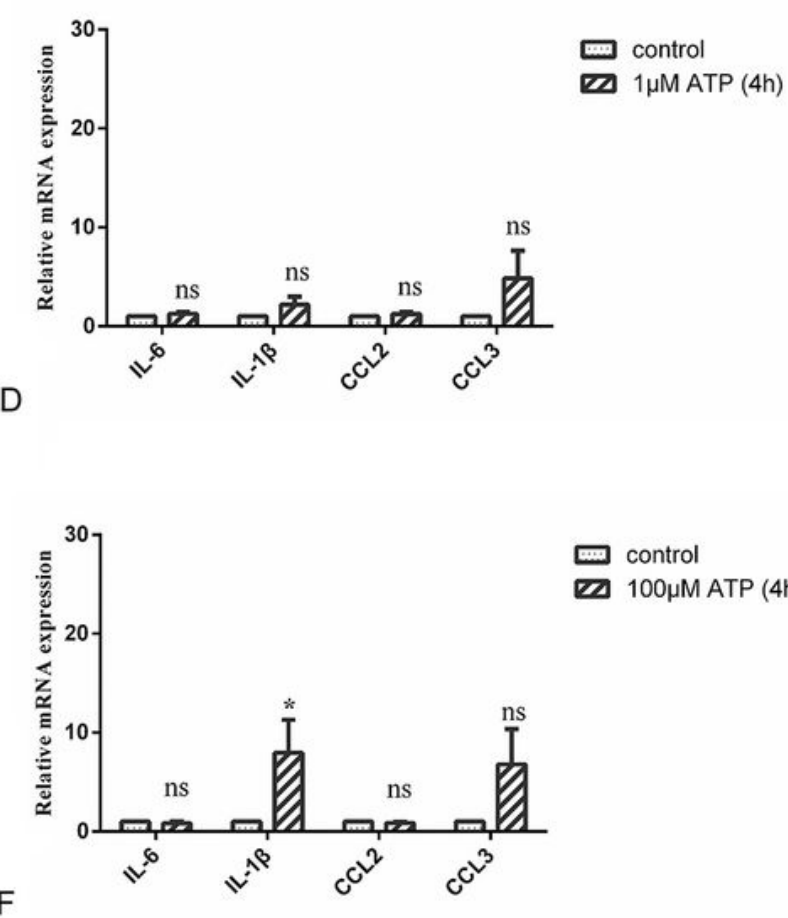

四 control

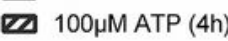

$\mathrm{F}$

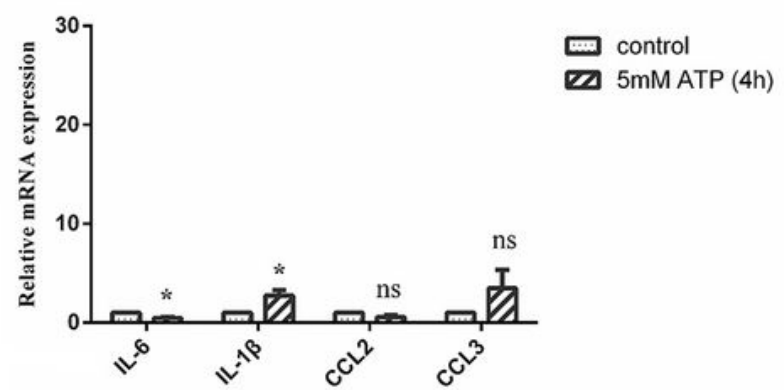

$\mathrm{H}$

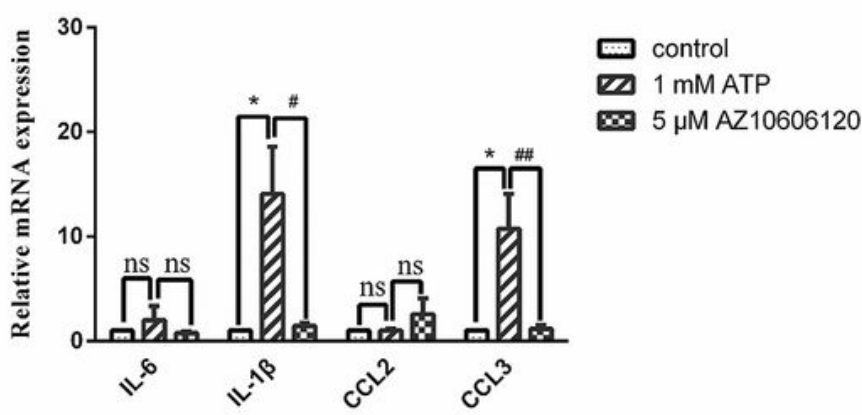

Figure 4

Mediators induced by different concentrations of extracellular ATP. (A) Histamine release significantly increased by adopting high concentrations of ATP ( $* p<0.05$, control vs 5 mM ATP). (B-H) The relative mRNA expression levels of IL-1 $\beta$, IL-6, CCL2 and CCL3 were regulated by different concentrations of ATP. After 4 hours of ATP treatment, there was no significant change in the expression of cytokines (B). IL-1 $\beta$ was up-regulated slightly induced by $10 \mu \mathrm{M}$ ATP or $100 \mu \mathrm{M}$ ATP (C, D) (* $p<0.05$, control vs $10 \mu \mathrm{M}$ ATP 
or $100 \mu \mathrm{M}$ ATP). IL-1 $\beta$ and CCL3 were up-regulated significantly induced by $1 \mathrm{mM} \mathrm{ATP}(\mathrm{E})\left({ }^{*} \mathrm{p}<0.05\right.$, ** $\mathrm{p}$ $<0.01$, $\star \star \star ~ p<0.001$, control vs $1 \mathrm{mM} \mathrm{ATP)}$. Cytokines were slightly up-regulated induced by $5 \mathrm{mM}$ ATP for 4 hours $(F)$ ( ${ }^{*} p<0.05$, control vs $5 \mathrm{mM} \mathrm{ATP}$ ), however, IL-1 $\beta$ and CCL3 were significantly up-regulated induced by $5 \mathrm{mM}$ ATP for 0.5 hours $(\mathrm{G})\left({ }^{*} p<0.05\right.$, $* * p<0.01$, $* \star * p<0.001$, control vs 5 mM ATP). (H) The up-regulation of IL-1 $\beta$ and CCL3 caused by $1 \mathrm{mM}$ ATP was blocked by specific P2X7 receptor antagonist AZ10606120. (* $p<0.05$, ** $p<0.01$, *** $p<0.001$, control vs 1 mM ATP; $\# p<0.05$, \#\#p< 0.01, \#\#\#p $<0.001,1 \mathrm{mM}$ ATP vs $5 \mu \mathrm{M}$ AZ10606120).

A

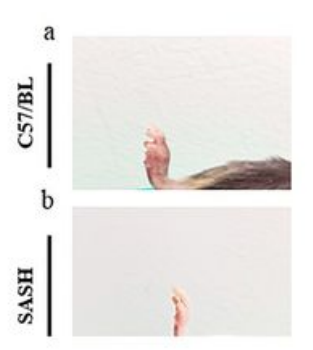

D
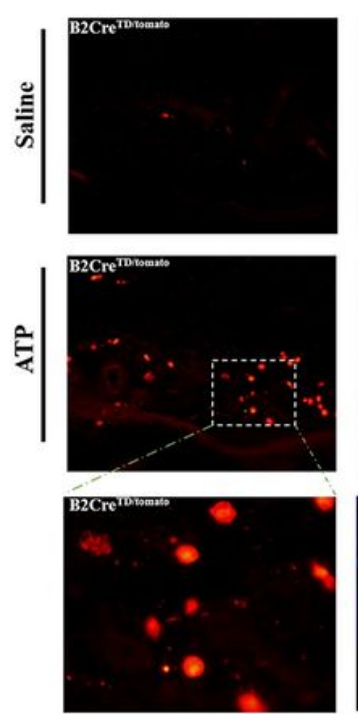

$\mathrm{F}$

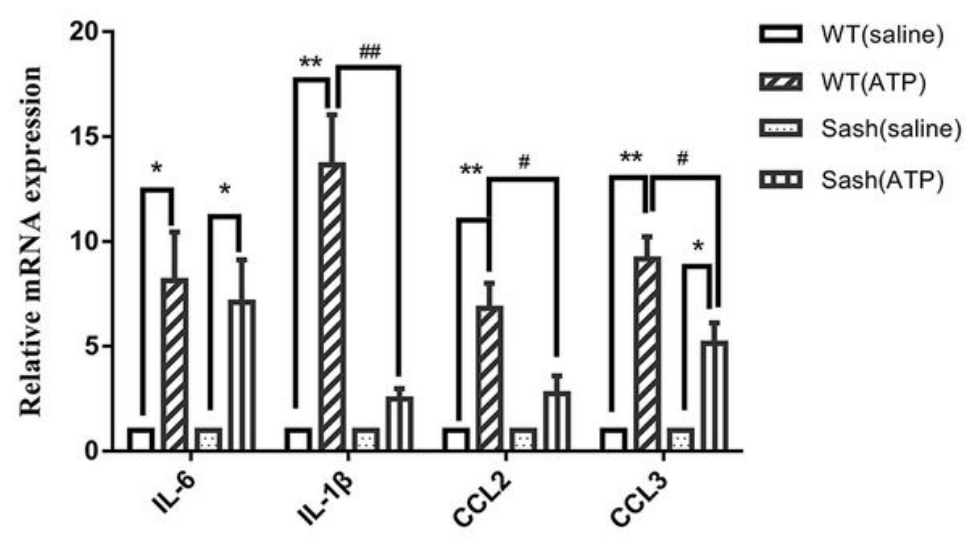

C

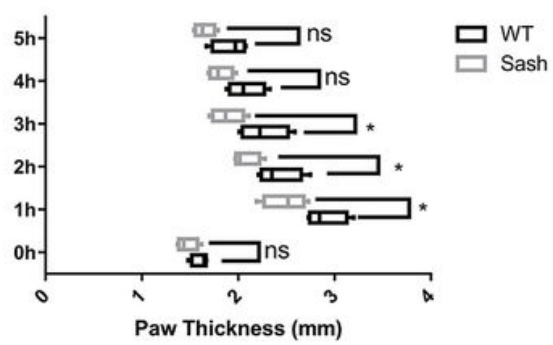

E

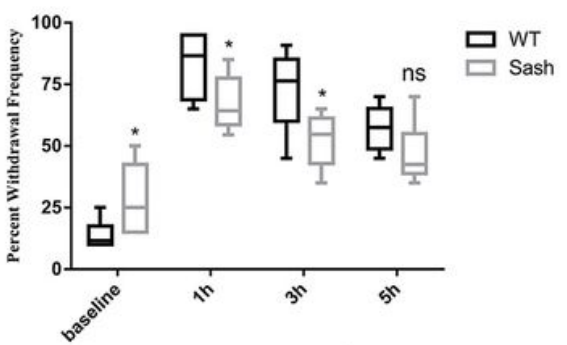

G

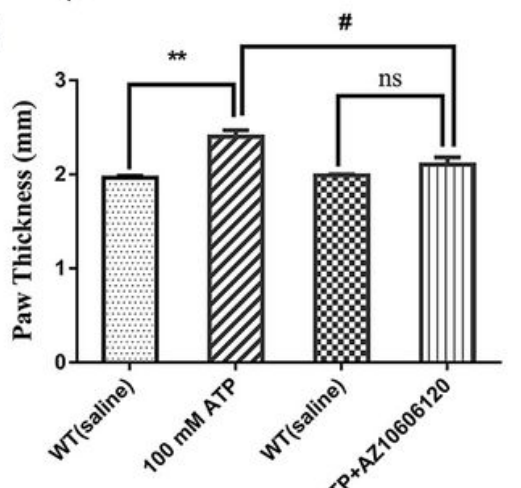

$\mathrm{H}$

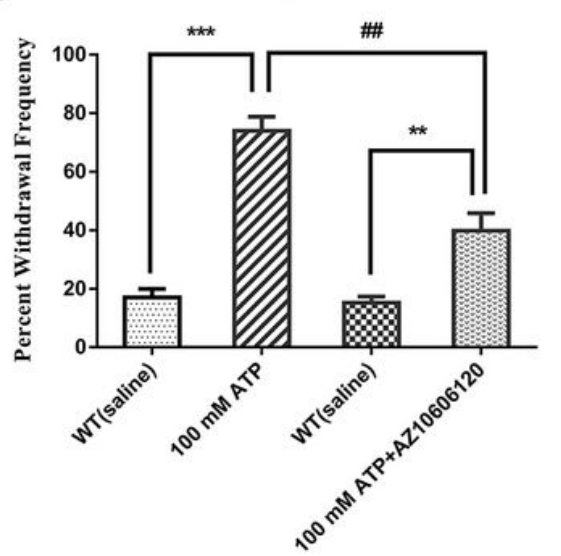

Figure 5 
Mast cell deficient and AZ10606120 alleviated high concentration ATP-induced pain. (A-C) Compared with C57/BL mice, sash mice alleviated the paw swelling (A), paw thickness (C) (* $p<0.05$, WT group vs Sash group, $n=8$ and 4 respectively) and the inflammatory cells infiltration (B) (a-b, HE staining of saline and ATP groups in C57/BL mice; c-d, HE staining of saline and ATP groups in Sash mice, 200X). (D) High concentration of ATP induced mast cells degranulation (MrgprB2CreTd/tomato mice, tdTomato fluorescent protein was integrated into the MrgprB2 promoter, red represented mast cell, and the small red particles around mast cells represent degranulation). (E) Sash mice alleviated the mechanical withdrawal threshold induced by high concentration of ATP $(* p<0.05$, WT group vs Sash group, $n=8$ and 4 respectively). (F) Mast cell deficient attenuated the up-regulation of several inflammatory factors including IL-6, IL-1 $\beta$, CCL2 and CCL3 (* $p<0.05$, ** $p<0.01$, *** $p<0.001$, saline group vs ATP group, \# $p$ $<0.05$, \#\# p < 0.01, \#\#\#p < 0.001, WT (ATP) group vs Sash (ATP) group). (G, H) AZ10606120 significantly relieved and the paw swelling $(G)$ and the mechanical withdrawal threshold $(H)(n=6) .\left({ }^{*} p<0.05, * \star p<\right.$ $0.01, * \star * p<0.001$, saline group vs ATP group or ATP+AZ10606120 group, $\# p<0.05, \# \# p<0.01, \# \# \# p<$ 0.001, ATP group vs ATP+AZ10606120 group). 
A

B

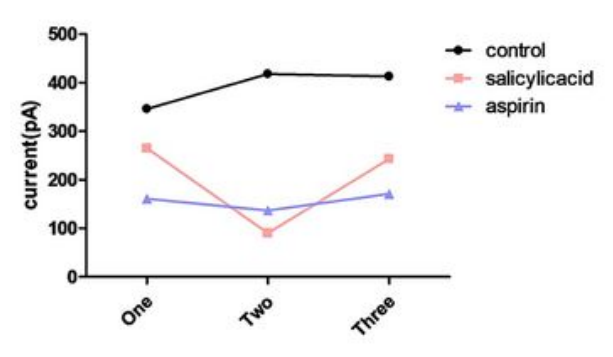

D

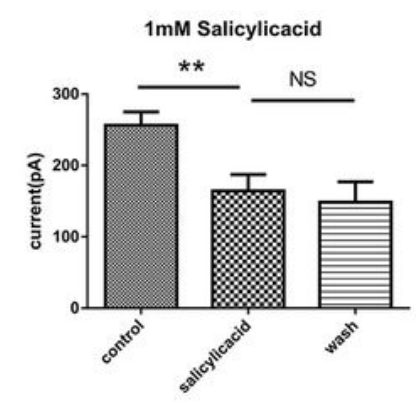

G

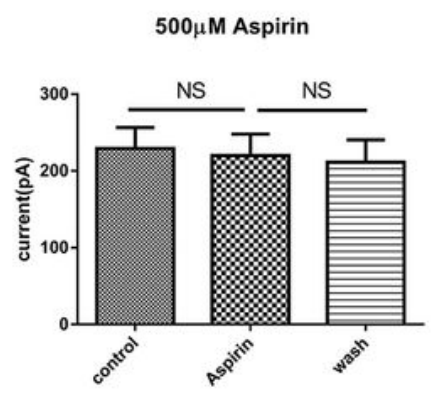

J

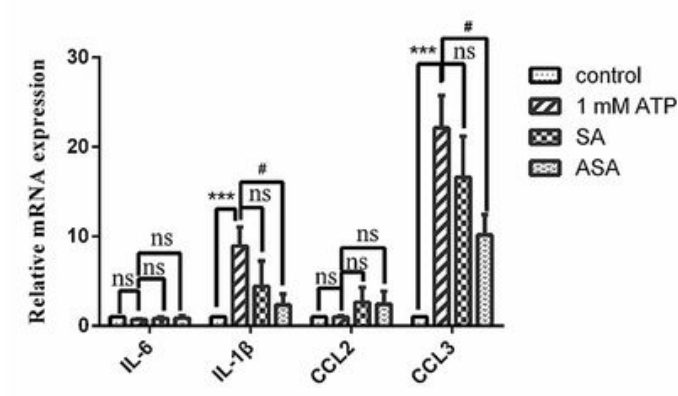

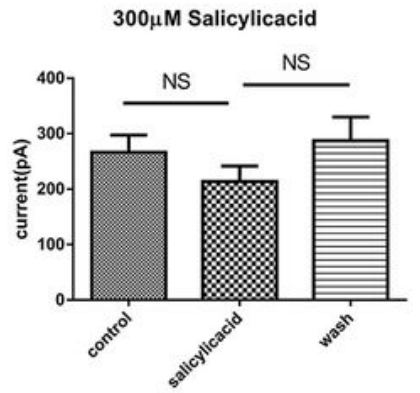

E

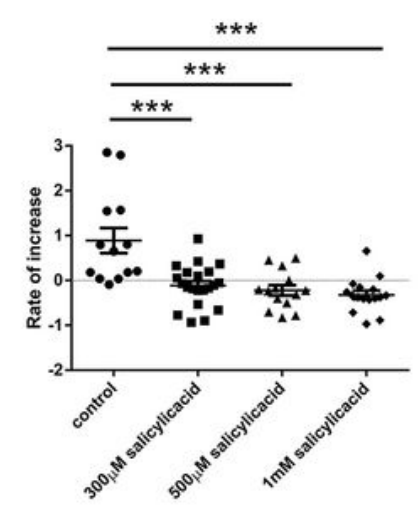

H

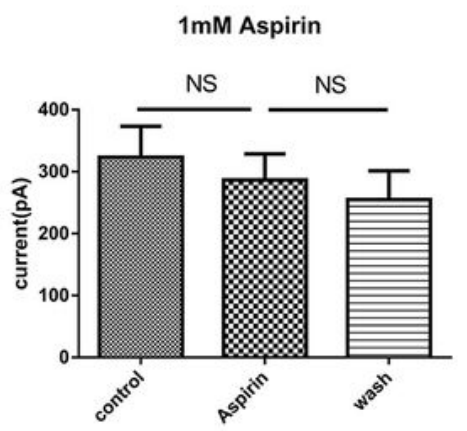

K

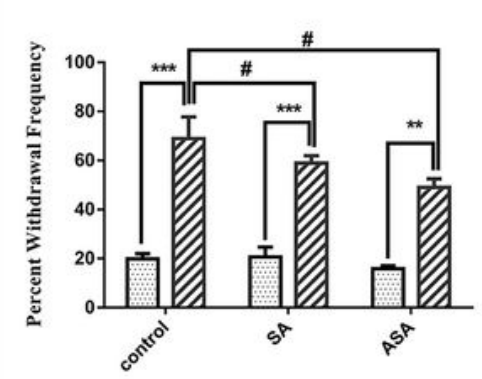

C

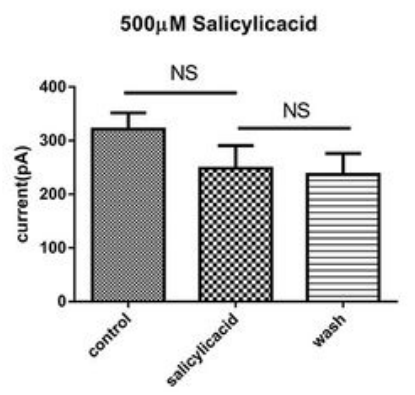

F

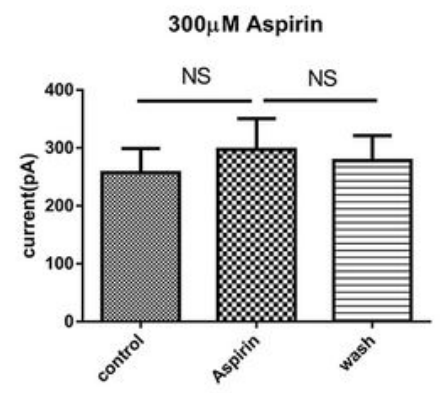

I

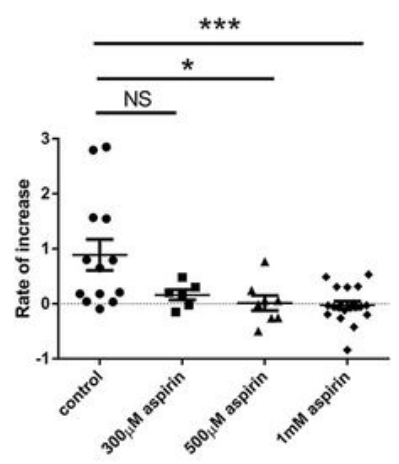

L

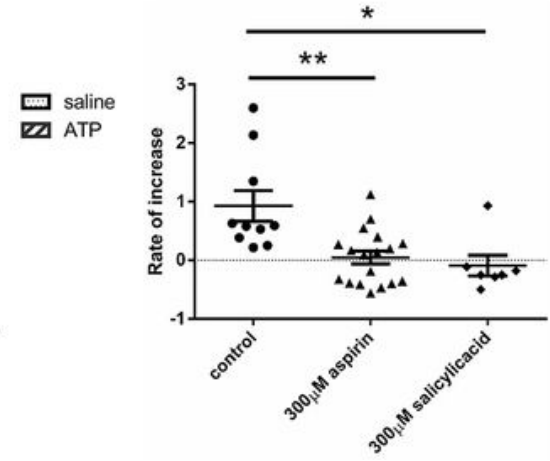

\section{Figure 6}

The effects of salicylic acid and aspirin on P2X7 receptor on mast cells. (A) Schematic diagram of the effect of salicylic acid and aspirin on inward current. (B-D) Salicylic acid inhibited the current induced by $5 \mathrm{mM}$ ATP. $300 \mu \mathrm{M}$ (B), $500 \mu \mathrm{M}$ (C) or $1 \mathrm{mM}$ salicylic acid (D) inhibited the current induced by second ATP application compared with that of first ATP application. (E) The current growth rate was significantly inhibited by different concentrations of salicylic acid. $(\mathrm{F}-\mathrm{H})$ Asprin inhibited the current induced by $5 \mathrm{mM}$ 
ATP. $300 \mu \mathrm{M}(\mathrm{F}), 500 \mu \mathrm{M}(\mathrm{G})$ or $1 \mathrm{mM}$ aspirin $(\mathrm{H})$ inhibited the current induced by second ATP application. (I) The current growth rate was significantly inhibited by different concentrations of aspirin. (J) $300 \mu \mathrm{M}$ Salicylic acid or $1 \mathrm{mM}$ aspirin blocked the up-regulation of cytokines mediated by P2X7 receptor. (K) Salicylic acid and aspirin alleviate peripheral pain induced by ATP with high concentration. (L) The current growth rate evoked by BzATP was significantly inhibited by $300 \mu \mathrm{M}$ salicylic acid or $300 \mu \mathrm{M}$ aspirin. ${ }^{*} p<0.05,{ }^{* *} p<0.01,{ }^{* * *} p<0.001 ; \# p<0.05, \# \# p<0.01, \# \# \# p<0.001$.

A

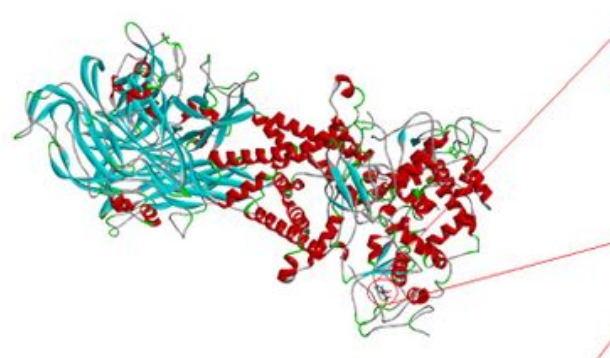

C

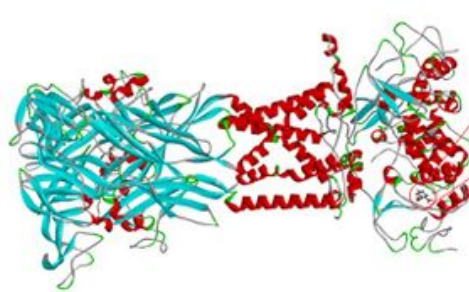

$\mathbf{E}$

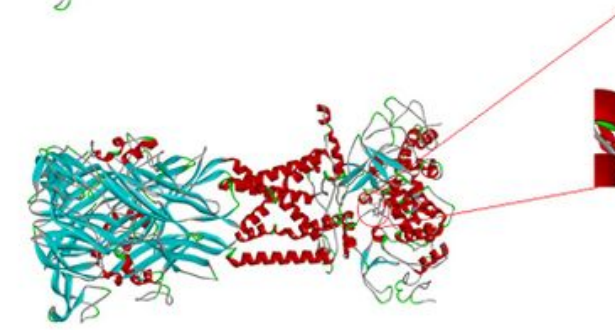

G

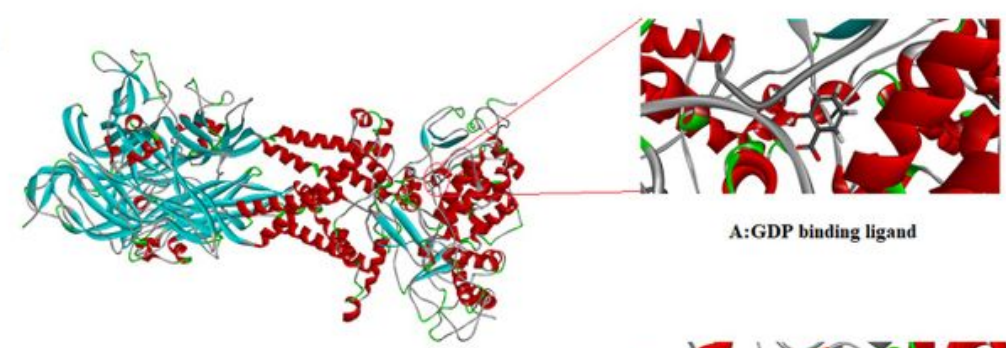

I

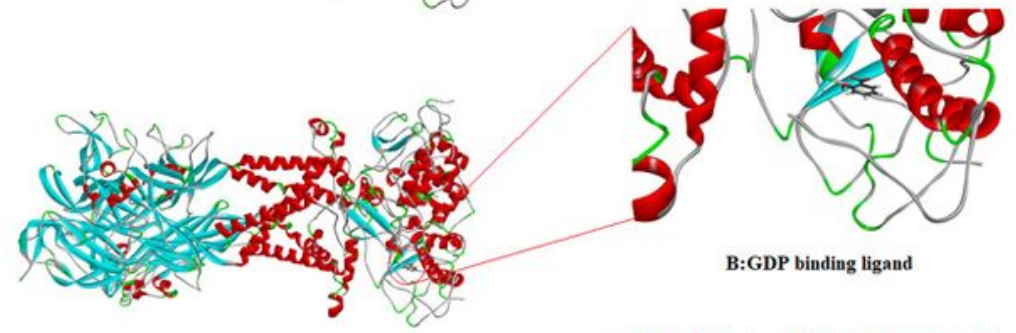

K

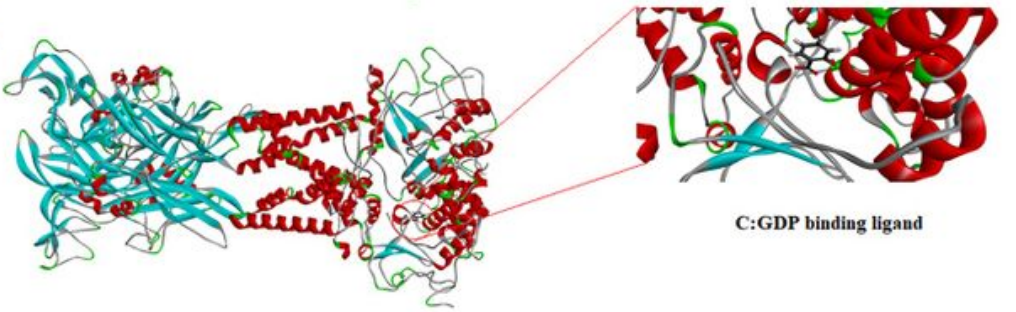

B

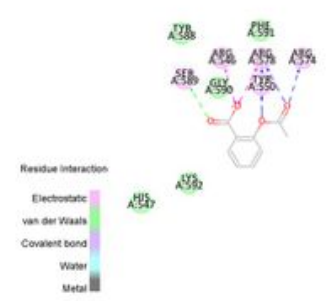

D

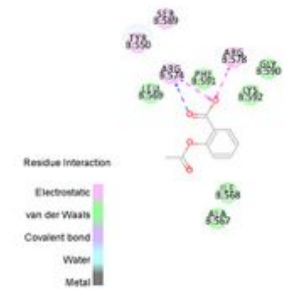

F

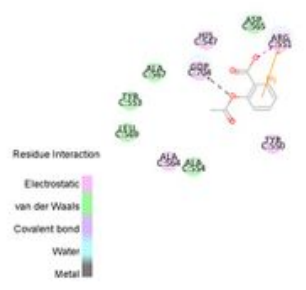

H

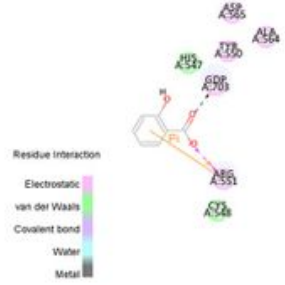

J

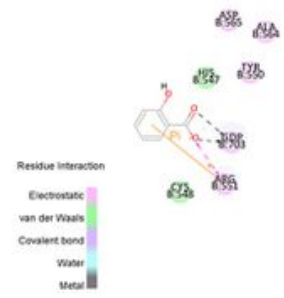

L

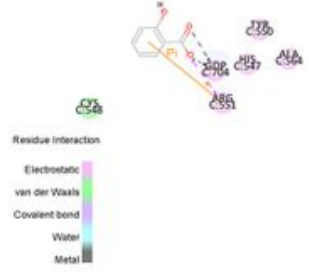

Figure 7 
Molecular docking of compounds with $\mathrm{P} 2 \mathrm{X} 7$ receptor. (A, B) Docking process of aspirin with the A: GDP703 ligand of P2X7 receptor; (C, D) Docking process of aspirin with the B: GDP703 ligand of P2X7 receptor; (E, F) Docking process of aspirin with the C: GDP704 ligand of P2X7 receptor; $(G, H)$ Docking process of salicylic acid with the A: GDP703 ligand of P2X7 receptor; $(\mathrm{I}, \mathrm{J})$ Docking process of salicylic acid with the B: GDP703 ligand of P2X7 receptor; $(K, L)$ Docking process of salicylic acid with the $C$ : GDP704 ligand of P2X7 receptor.

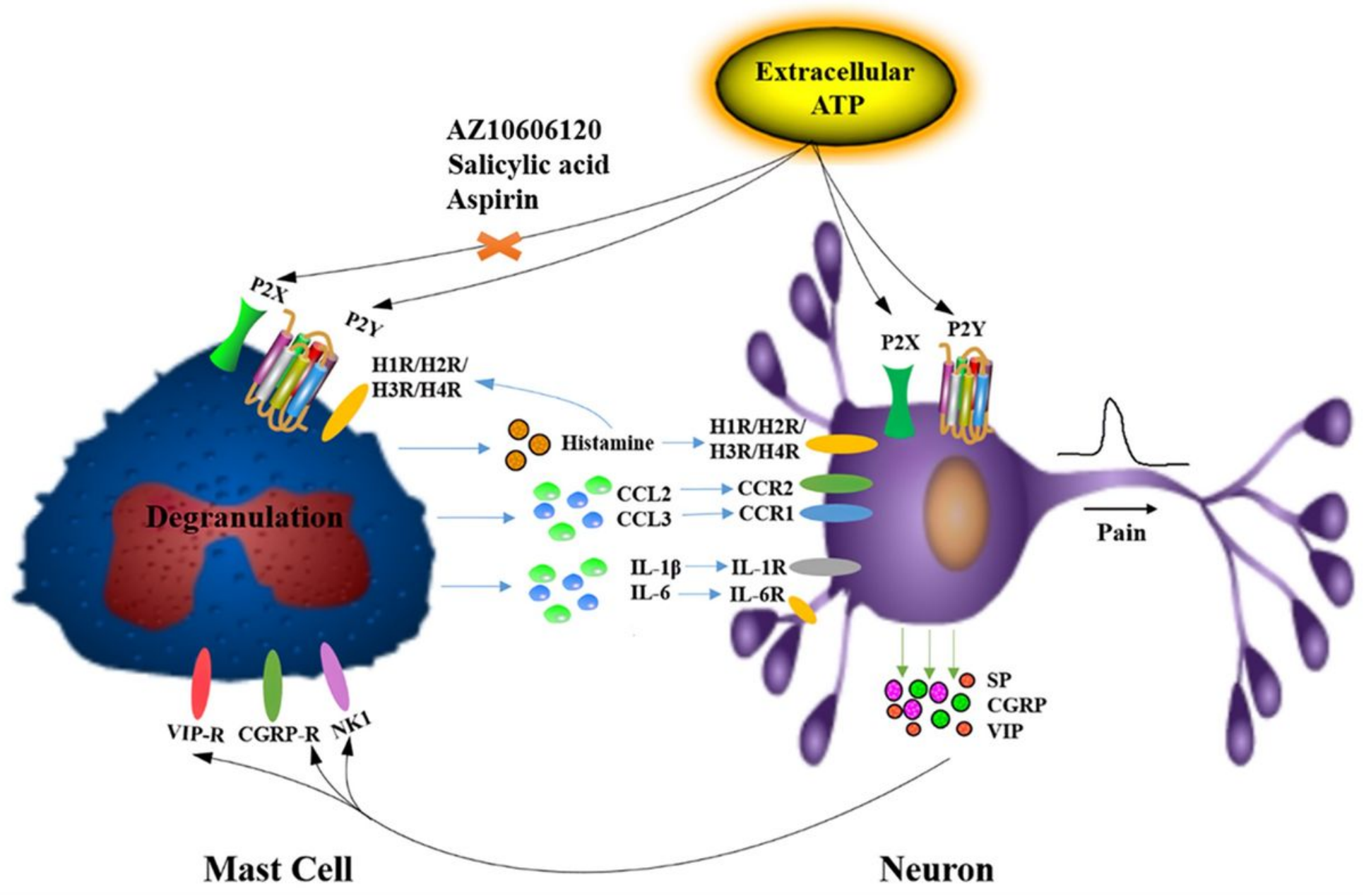

Figure 8

The mechanism of pain induced by extracellular ATP via neuron-immune crosstalk.

\section{Supplementary Files}

This is a list of supplementary files associated with this preprint. Click to download.

- supplementary.pdf 